\title{
REVISITING “SPLIT ERGATIVITY” IN CAVINEÑA ${ }^{1}$
}

\author{
Antoine Guillaume \\ DDL - CNRS - UNIVERSITÉ LYON 2
}

\begin{abstract}
Cavineña, an ergative language spoken in Amazonian Bolivia, has a very intriguing pronominal system where, notably, a pronoun coding a transitive subject can either have a full "ergative" form or a reduced form that makes it look like an "absolutive" pronoun (used to code an intransitive subject or a transitive object). Camp (1985) describes the system as an instance of "split ergativity" conditioned by the difference between main and subordinate clause, the mood/polarity of the clause, the constituent order, and a person hierarchy. The phenomenon of split ergative systems was first discussed in the 1970s (by Dixon 1972; 1979, Silverstein 1976, and Comrie 1978, among others) and this certainly influenced Camp's "split ergative" analysis. The goal of this paper is to reevaluate Camp's analysis in the light of new findings about the coding of grammatical functions in this language. It is shown that the peculiarities of the Cavineña pronominal system can be accounted for in a more elegant explanatory and typologically plausible way by recognizing a distinction between independent pronouns and bound pronouns and the application of a simple morphophonological rule.
\end{abstract}

[KEYWORDS: split ergativity, independent/bound pronouns, second-position clitics, Tacanan family, Amazonian languages]

1. Introduction. Cavineña is an endangered language spoken by fewer than 1,200 people in the Amazonian rainforest of northern Bolivia. It belongs to the Tacanan family, together with Araona, Ese Ejja, Reyesano, and Tacana. ${ }^{2}$ Cavineña is an ergative language with a very intriguing pronominal system where, notably, a pronoun coding a transitive subject can either have

${ }^{1}$ I wish to thank the Cavineña people for their friendliness, hospitality, and cooperation during my project to document their language. Alfredo Tavo stands out for his genuine interest in his Cavineña language and in my work. I am also grateful for the academic and financial support offered to me by Sasha Aikhenvald and Bob Dixon through the Research Centre for Linguistic Typology (RCLT, La Trobe University) between 2000 and 2004 as I was writing my Ph.D. dissertation on Cavineña, and to the Pieter Muysken and the Spinoza project (Netherlands) for funding a field trip in 2000. This paper was given at RCLT (November 2003), at the Syntax of the World's Languages conference (SWL1, Leipzig, August 2004) and at the Third Meeting of the Programme International de Coopération Scientifique (PICS) on 'L'ergativité en Amazonie' (CELIA-CNRS, IRD, and LALI-UnB, Villejuif, December 2004). Finally, the paper benefited from comments by Denis Creissels, Scott Delancey, Bob Dixon, and Colette Grinevald, as well as the editorial team of IJAL: Keren Rice, Willem Adelaar, and two anonymous reviewers.

${ }^{2}$ A sociolinguistic presentation of Cavineña and a comprehensive grammatical description (836 pages) can be found in Guillaume (2004). The grammar includes a fully detailed discussion of the pronominal system of the language (2004:chap. 15). My research on Cavineña is based on my firsthand experience with the Cavineña language and its speakers. It draws on

[IJAL, vol. 72, no. 2, April 2006, pp. 159-92]

(C) 2006 by The University of Chicago. All rights reserved.

0020-7071/2006/7202-0001\$10.00 
a full "ergative" form or a reduced form that makes it look like an "absolutive" pronoun (used to code an intransitive subject or a transitive object). Camp (1985) describes the system as an instance of "split ergativity" conditioned by the difference between main and subordinate clause, the mood/polarity of the clause, the constituent order, and a person hierarchy. The phenomenon of split ergative systems was first discussed in the 1970s (by Dixon 1972; 1979, Silverstein 1976, and Comrie 1978, among others) and this certainly influenced Camp's "split ergative" analysis. The goal of this paper is to reevaluate Camp's analysis in the light of new findings about the coding of grammatical functions in this language. It is shown that the peculiarities of the Cavineña pronominal system can be accounted for in a more elegant explanatory and typologically plausible way by recognizing a distinction between independent pronouns and bound pronouns and the application of a simple morphophonological rule.

1.1. Coding of grammatical functions by nouns/NPs. Cavineña is an ergative dependent-marking language with head-final properties. ${ }^{3}$ Grammatical functions are coded by a system of case markers which are enclitics to the last phonological word of NPs (or suffixes in the case of pronouns; see 1.2 below). An NP in A function (transitive subject) takes the marker $=r a$

about 15 months of fieldwork (six field trips) between 1996 and 2003, half in the small town of Riberalta and half in traditional communities. About 60 texts and conversations were recorded, transcribed, and translated (they amount to about 5,000 sentences). Another 20 texts were written by Cavineña consultants (about 700 sentences). The corpus was complemented by utterances volunteered by speakers or elicited during controlled sessions as well as utterances overheard during participant observation (about 3,600 sentences). Finally, I have made use of Cavineña texts collected and published by SIL missionaries Camp and Liccardi (such as Camp and Liccardi 1972 or Tavo Mayo 1977) (about 3,500 sentences) and the sentences that illustrate the entries of their (1989) dictionary (about 3,000 sentences).

${ }^{3}$ Cavineña vowel phonemes are $i, e$ (with allophones [e] and $[\varepsilon]$ in free variation), $a$ and $v$ (written $u$; with allophones [v] and [o] in free variation). Cavineña consonant phonemes are $p$, $b, t, d, c$ (alveo-palatal voiceless stop; written $t y), f$ (alveo-palatal voiced stop; written $d y$ ), $k$, $k w, t s$ (alveolar affricate; corresponding to Camp's $\not$ ), tc (alveo-palatal affricate; written $c h$; corresponding to Camp's $\breve{c}$ ), $s, c$ (alveo-palatal fricative; written $s h$; corresponding to Camp's $\check{s}$ ), $h$ (written $j$; corresponding to Camp $h$ ), $l$ (alveolar lateral flap; written $r$ ), $\alpha$ (alveo-palatal liquid; written $l y$; corresponding to Camp's $l l$ ), $m, n, n$ (written $n y$; corresponding to Camp $\tilde{n}$ ), $w$ (with allophones [w] before $a$ and [ $\left.\beta_{\top}\right]$ before $i$ and $e$ ), and $j$ (written $y$ ). Syllable structure is (C)V. Cavineña has a noncontrastive pitch accent system whose role is the delimitation of the phonological word as a prosodic domain. It is realized as follows: (1) the first syllable of a phonological word receives a high pitch, (2) the last two syllables receive a mid pitch (the last syllable only if it is a two-syllable word), and (3) the high pitch of the first syllable extends rightward to any syllable before the last two syllables. (A low pitch is used to code utterance boundaries.) Some words borrowed from Spanish have not integrated the Cavineña phonological system at all and are pronounced just as in Spanish. In this study, they are written according to their Spanish orthography (e.g., carga 'load', escuela 'school', Señor 'Lord', etc.). See Guillaume (2004:chap. 2) for a full account of Cavineña phonology. 
'ERG' (as with iba 'jaguar' in 1a). ${ }^{4} \mathrm{An} \mathrm{NP}$ in $\mathrm{S}$ function (intransitive subject) is unmarked for case (as with $i b a$ 'jaguar' in $1 b$ ), similarly to an NP in $\mathrm{O}$ function (transitive object) (as with takure 'chicken' in 1a).

(1a) Transitive clause

$\begin{array}{llll}{\text { Iba }=\boldsymbol{r} \boldsymbol{a}_{\mathrm{A}}} & =t u_{\mathrm{O}} & \text { iye-chine } & \text { takure }_{\mathrm{O}} . \\ \text { jaguar=ERG } & =3 \mathrm{SG} & \text { kill-REC.PAST } & \text { chicken.ABS }\end{array}$

'The jaguar killed the chicken'.

(1b) Intransitive clause

$\begin{array}{rllll}{[\text { Tu-ke }} & \text { tupuju }] & =t u_{\mathrm{S}} & \boldsymbol{i b a _ { \mathrm { S } }} & \\ \text { 3SG-FM behind } & =3 \mathrm{SG} & \text { jaguar.ABS } & \text { run-REC.PAST }\end{array}$

'The jaguar ran behind him (i.e., the jaguar chased him)'. (Camp and Liccardi 1972:33)

Grammatical functions are only coded by case marking. Constituent order is free and there are no pronominal markers in the verb/predicate.

Obliques are also coded by case markers, as with the dative enclitic $=j a$ 'DAT' in $(2 a)$ and the locative enclitic $=j u$ 'LOC' in $(2 b)$. (A number of obliques are coded by phonologically independent markers, as with tupuju 'behind' in $1 b$.)

(2a) Bari=ja $=t u_{\mathrm{S}} \quad \mathrm{rapa}_{\mathrm{S}}$ bijida.

anteater $=\mathrm{DAT} \quad=3 \mathrm{SG}$ termite nice

'Anteaters like termites (lit., termites are nice to anteaters)'. (Camp and Liccardi 1989:10)

(2b) $J u$-ti-kware $=d y a \quad=\emptyset_{\mathrm{S}} \quad[$ Arauna $=\boldsymbol{k} w \boldsymbol{w a n a}=\mathbf{j a}$

be-GO-REM.PAST $=$ FOC $=1 \mathrm{SG} \quad$ Araona.person $=\mathrm{PL}=\mathrm{GEN}$

epu=ju].

village $=$ LOC

'I arrived at the village of the Araonas'.

\footnotetext{
${ }^{4}$ Abbreviations used in this paper are: A transitive subject; ABIL abilitative; ABS absolutive; ASSOC associative; CONTR contrastive; DAT dative; DIM diminutive; DL dual; DS different subject; EMPH emphatic; ERG ergative; FILL filler; FM formative; FOC focus; FRUST frustrative; GEN genitive; HORT hortative; IMP imperative; IMPFV imperfective; INCR incrementative; LIG ligature; LOC locative; NEG negative; O transitive object; PERF perfect; PL plural; POT potential; REC.PAST recent past; REITR reiterative; REM.PAST remote.past; REP reportative; RES resultative; $S$ intransitive subject; SG singular; ss same subject; STRG.EMPH strong emphasis; sUB subordinate clause; UNCERT uncertainty.

${ }^{5}$ When no indication of the source of an example is provided, the example comes from my own corpus.
} 
TABLE 1

CAVINEÑA Pronouns (ACCORDING TO CAMP 1985:40)

\begin{tabular}{lclll}
\hline \hline Case & Person & \multicolumn{1}{c}{ SG } & \multicolumn{1}{c}{ DL } & \multicolumn{1}{c}{ PL } \\
\hline ABS & 1 & $i-k e /=\emptyset$ & yatse & ekwana \\
& 2 & mi-ke/=mi & metse & mikwana \\
& 3 & tu-ke/=tu & tatse & tuna \\
ERG & 1 & $e-r a$ & yatse-ra & ekwana-ra \\
& 2 & mi-ra & metse-ra & mikwana-ra \\
& 3 & tu-ra & tatse-ra & tuna-ra \\
GEN & 1 & e-kwe & yatse-ja & ekwana-ja \\
& 2 & mi-kwe & metse-ja & mikwana-ja \\
& 3 & tu-ja & tatse-ja & tuna-ja \\
\hline
\end{tabular}

An NP coding a possessor within an NP takes the genitive enclitic $=j a$ ' $\mathrm{GEN}$ ' and must precede the head of the NP (the possessee), as in $(2 b){ }^{6}$

The coding of grammatical functions by nouns or NPs is straightforward. Nouns/NPs expressing core arguments always follow the above ergative pattern; a noun/NP in A function is always marked by $=r a$ 'ERG' and a noun/NP in $\mathrm{S}$ or $\mathrm{O}$ function is always unmarked. When it comes to pronouns, the situation is more complex, as described below.

1.2. Coding of grammatical functions by pronouns. According to Camp (1985) (and repeated in Camp and Liccardi 1978; 1983; 1989), Cavineña has the inventory of pronouns shown in table $1 .^{7}$

We can see that there are three number distinctions: singular versus dual versus plural. Absolutive singular pronouns have two forms: a full form (on the left) and a short form (on the right). Full forms roughly correspond to the short forms plus the suffix $-k e$. Ergative and genitive pronouns roughly correspond to the forms of the absolutive pronouns (short forms in the case of singular pronouns) plus the ergative suffix - $r a$ 'ERG' or the genitive suffix $-j a$ 'GEN' (or a suffix - $k w e$ in the case of first- and second-person singular). ${ }^{8} \mathrm{Ac}-$ cording to Camp, the short forms of absolutive singular pronouns are enclitics - they attach phonologically to a preceding word-while the rest of the pronouns are phonologically independent. ${ }^{9}$

${ }^{6}$ Note that the genitive marker is homophonous with the dative marker. See Guillaume (2004:537ff.) for a justification for treating them as distinct morphemes.

${ }^{7}$ Camp's table has been slightly modified. I have segmented/hyphenated the pronouns and added the symbol $=$ to code clitics. Additional modifications are discussed below.

${ }^{8}$ Note that the suffixes - $r a$ 'ERG' and -ja 'GEN' are homophonous with and clearly related to the ergative and genitive/dative case markers $=r a$ 'ERG' and $=j a$ 'GEN/DAT', respectively. See Guillaume (2004:529-93) for a justification for treating them as different morphemes.

${ }^{9}$ Note that I later argue against this dichotomy. The rest of the pronouns can be either independent phonologically (as argued by Camp) or enclitics as well. 
Camp's pronominal system includes additional third-person pronouns. There is first a series of third-person proximal pronouns. These pronouns behave almost exactly like the third-person (distal) pronouns and will not be discussed here. There are also two third-person absolutive "quantitative" pronouns (dual ekatse '3DL' and plural ekana '3PL'). These two forms differ from other pronouns in many ways and may not be pronouns at all. They will therefore not be part of the present discussion. Finally, the system includes a series of forms that Camp calls "dative" pronouns. These correspond to special pronominal roots used to code comitative and locative obliques (e.g., $e a$ ' $1 \mathrm{sG}$ ' in ea-tsewe 'with me'). ${ }^{10}$ Like third-person proximal pronouns and "quantitative" pronouns, Camp's "dative" pronouns are not relevant to the following discussion and have not been included in table 1. (Full details on proximal pronouns, "quantitative" pronouns, and "dative" pronouns can be found in Guillaume 2004:chap. 15.)

Grammatical functions are coded by pronouns as follows. Nonsingular arguments in $\mathrm{S}$ or $\mathrm{O}$ function are coded by absolutive pronouns with a straightforward single form, as with metse '2DL' coding $\mathrm{S}$ in $(3 a)$ and $\mathrm{O}$ in (3b).

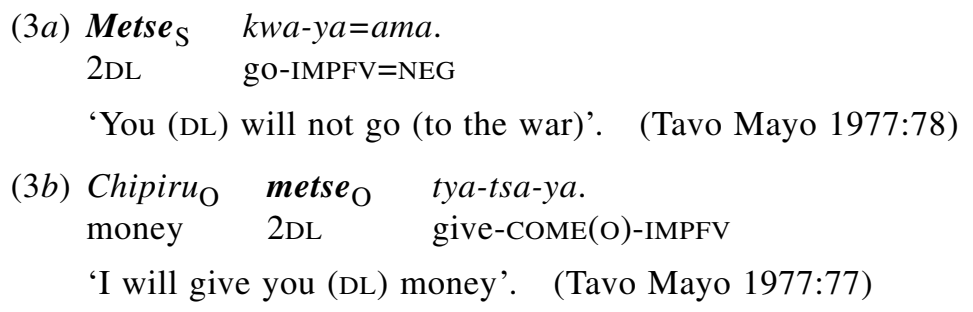

Singular arguments in $\mathrm{S}$ or $\mathrm{O}$ function, on the other hand, can be coded either by short absolutive forms (as with $=m i$ ' $2 \mathrm{sG}$ ' coding $\mathrm{S}$ in $4 a$ and $=t u$ ' $3 \mathrm{sG}$ ' coding $\mathrm{O}$ in $5 a$ ) or by full absolutive forms (as with $m i-k e$ ' $2 \mathrm{sG}-\mathrm{FM}$ ' coding $\mathrm{S}$ in $4 b$ and $t u-k e$ '3SG-FM' coding $\mathrm{O}$ in $5 b$ ).

(4) Intransitive clauses

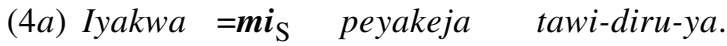
now $=2 \mathrm{SG}$ other.place sleep-GO-IMPFV

'Now you (sG) are going to sleep somewhere else'. (Camp 1985:53)
(4b) Je-nuka-ya=ama
$m i-k e_{\mathrm{S}}$ ?
come-REITR-IMPFV=NEG
2SG-FM
'Will you (SG) not come again?'

\footnotetext{
${ }^{10}$ In my analysis, the term "dative" refers to a different case. See the dative enclitic $=j a$ in (2a) and dative pronouns below.
} 
(5) Transitive clauses

(5a) $\boldsymbol{M i}-\boldsymbol{r a} \boldsymbol{A}_{\mathrm{A}} \quad \boldsymbol{t} \boldsymbol{u}_{\mathrm{O}} \quad b a-y a=a m a ?$

$2 \mathrm{SG}-\mathrm{ERG} \quad=3 \mathrm{SG} \quad$ see-IMPFV $=\mathrm{NEG}$

'Don't you (SG) see it?'

(5b) Ejebucha tu-ke $\boldsymbol{O}_{\mathrm{O}}=\boldsymbol{m i}_{\mathrm{A}}$ ba-ya?

how $3 \mathrm{SG}-\mathrm{FM} \quad=2 \mathrm{SG}$ see-IMPFV

'How do you (SG) see it?'

Arguments in A function, similarly to singular arguments in S/O function, can be coded by pronouns with either a full (ergative) form or a short form. Unlike singular arguments in S/O function, however, the alternation applies to any number. A full ergative pronoun coding a singular argument in A function can be seen with $m i-r a$ ' $2 \mathrm{SG}-\mathrm{ERG}$ ' in $(5 a)$. Its corresponding short form $=m i$ ' $2 \mathrm{sG}$ ' appears in $(5 b)$. A full ergative pronoun coding a dual argument in A function can be seen with metse-ra '2DL-ERG' in ( $6 a)$, while its corresponding short form metse '2DL' appears in (6b).

(6a) Pake metse-ra $a_{\mathrm{A}} \quad[e-k w e \quad \text { utsekwa }]_{\mathrm{O}}$ apparently 2DL-ERG 1SG-GEN grandchild

naru - chine $=$ ama .

take.care. of-REC.PAST $=$ NEG

'Apparently you (DL) didn't take care of my grandchild'. (Camp 1985:42)

(6b) Tapeke $_{\mathrm{O}}$ metse $_{\mathrm{A}}$ ara-ya=ama?

trip.food 2DL eat-IMPFV=NEG

'Don't you (DL) want to eat the food (that I brought for the trip)?'

Incidentally, singular short ergative pronouns are formally identical to singular short absolutive pronouns: $=m i$ ' $2 \mathrm{sG}$ ' coding $\mathrm{A}$ in $(5 b)$ is formally identical to $=m i$ ' $2 \mathrm{sG}$ ' coding $\mathrm{S}$ in $(4 a)$; and nonsingular short ergative pronouns are formally identical to nonsingular absolutive pronouns: metse '2DL' coding $\mathrm{A}$ in $(6 b)$ is formally identical to metse '2DL' coding $\mathrm{S}$ in (3a) and $\mathrm{O}$ in $(3 b)$. As we shall see, this formal similarity is the starting point of Camp's "split ergativity" analysis.

Genitive pronouns are used to code a possessor within an NP. They must precede the NP head (the possessee) exactly like a genitive NP (cf. $2 b$ ), as shown in (7).

(7) $T i b u=r a_{\mathrm{A}}=\emptyset_{\mathrm{O}} \quad$ duju-kware $\quad[$ tuna-ja epu=ju]. $\mathrm{Tibu}=\mathrm{ERG}=1 \mathrm{SG}$ take-REM.PAST $3 \mathrm{PL}-\mathrm{GEN} \quad$ village $=\mathrm{LOC}$

'Tibu took me to their village'. 
Although not noted by Camp, the same pronominal forms that code a possessor within an NP (in genitive function) can also have a dative function, in which case they operate at the clause level. This is illustrated with $e$-kwe '1SG-DAT' in (8).

E-kwe ani-kware $\quad[$ maletero
1SG-DAT
sit-REM.PAST bag
'I had a big bag (lit., a big bag sat to me)'.

1.3. Outline of Camp's analysis and its shortcomings. From the formal identity between short ergative forms and absolutive pronouns, Camp concludes that A can be coded identically to $\mathrm{S}$ by way of a unique set of "absolutive" pronouns. In Camp's terms, pronouns in A function are either "ergative" or "absolutive"; her set of ergative pronouns does not include the shortened variants (see table 1). Furthermore, since A and S can be coded either differently or identically, she says that Cavineña is a "split ergative" language. Based on typological literature on ergativity available at the time (notably Dixon 1979, although not explicitly cited in the article), Camp proceeds to show that the Cavineña "ergative split" (i.e., the alternation affecting pronouns in A function) is essentially conditioned by a combination of the following four factors: (1) the difference between main and subordinate clause, (2) the mood/polarity of the clause, (3) the constituent order, and (4) a $1>2>3$ person hierarchy.

Let us consider (5) (repeated below) in the light of Camp's analysis. In $(5 b)$, according to Camp, there is a "split" (i.e., the A pronoun is coded by what she calls an "absolutive" pronoun) because the person of the A (second person) is higher than the person of the $\mathrm{O}$ (third person) on the hierarchy (factor 4 above). In ( $5 a$ ), on the other hand, even though we have the same person combination (A2/O3), there is no "split" (i.e., the A pronoun is coded by what she calls an "ergative" pronoun) because the A pronoun occurs first in the sentence (factor 3) and because factor (3) has precedence over factor (4).

(5a) $\boldsymbol{M i}-\boldsymbol{r a} \boldsymbol{A}_{\mathrm{A}} \quad=t \boldsymbol{u}_{\mathrm{O}} \quad b a-y a=a m a ?$

$2 \mathrm{SG}-\mathrm{ERG} \quad=3 \mathrm{SG} \quad$ see-IMPFV=NEG

'Don't you (SG) see it?'

$(5 b)$

$\begin{array}{llll}\text { Ejebucha } & \boldsymbol{t u}-\boldsymbol{k} \boldsymbol{e}_{\mathrm{O}} & =\boldsymbol{m i} & \\ \text { how } & 3 \mathrm{SG}-\mathrm{FM} & =2 \mathrm{SG} & \text { see-IMPFV }\end{array}$

'How do you (sG) see it?'

Credit must be given to Camp for having drawn attention to a very complicated pronominal system. However, her analysis is not convincing for several reasons. First, while ergative splits conditioned by each of the four 
factors proposed by Camp or by closely related factors are attested crosslinguistically (Dixon 1994:70ff.), the combination of the four is not, to my knowledge, attested in the literature, and the system proposed by Camp is an unusually complicated one. Second, the characterization of the pronominal coding patterns as "split ergative" does not take the coding of the $\mathrm{O}$ argument into account. A prototypical split ergative language is one in which $\mathrm{S}, \mathrm{A}$, and $\mathrm{O}$ are either coded according to an ergative/absolutive pattern (A $\neq \mathrm{S}=\mathrm{O}$ ) or according to a nominative/accusative pattern $(\mathrm{A}=\mathrm{S} \neq \mathrm{O})$ (Dixon 1994:70, Lazard 1994:60-61, and Payne 1997:161). In Camp's analysis of Cavineña, the ergative/absolutive pattern never alternates with a nominative/accusative pattern $-\mathrm{O}$ is never coded differently. Third, the analysis leaves a number of other facts unaccounted for. These include the fact that second position plays an important role in the pronominal system, the fact that a pronoun can co-occur with a noun/NP referring to the same argument in the same clause, and that the alternation between full forms and short forms of absolutive singular pronouns is conditioned by basically the same set of factors that condition the alternation between full forms and short forms of ergative pronouns. These and other problems with Camp's analysis are examined in detail in $\mathbf{3}$ below, following a full presentation of her analysis in 2 .

1.4. Outline of the proposed reanalysis. The main points of my proposal consist of (a) recognizing a distinction between two different categories of pronouns in Cavineña (as opposed to a single category, as per Camp): independent pronouns and bound pronouns, and $(b)$ attributing the odd facts to the application of a morphophonological rule of suffix deletion. The proposal can be outlined as follows. First, Cavineña has independent pronouns. These fill NP slots and, similarly to nouns/NPs, distribute freely in any type of clause. Independent pronouns only have full forms (they do not have short forms). Second, Cavineña has bound pronouns. Bound pronouns have the same morphological makeup as independent pronouns but very different prosody and syntactic distribution. They are unaccented second-position enclitics ${ }^{11}$ which are found only in certain types of main clauses and with strict ordering restrictions controlled by a person hierarchy. Bound pronouns, unlike independent pronouns, can be subject to the application of a morphophonological rule that deletes the suffix - $r a$ (from ergative pronouns) or the suffix -ke (from absolutive pronouns) under certain circumstances. It is the workings of this morphophonological rule applied to bound pronouns that

\footnotetext{
${ }^{11}$ Reminiscent of second-position pronouns found in some Australian languages like Ngiyambaa (Donaldson 1980, cited in Dixon 2002:374) or Walbiri (Hale 1973) and in UtoAztecan languages such as Luiseño (Steel 1976, cited in Bickel and Nichols [forthcoming]), for example.
} 
causes the impression that, in Cavineña, a pronoun coding an argument in A function can be identical in form to a pronoun coding an argument in $\mathrm{S}$ function and that made Camp analyze Cavineña as a "split ergative" language.

Let us reconsider (5) (repeated again below) in the light of the proposed reanalysis. In (5b), the A pronoun has a short form because it is a bound pronoun (in second position) and because it has lost its ergative suffix -ra due to the application of the deletion rule. In $(5 a)$, the A pronoun has a full form because it is an independent pronoun (in sentence-initial position) which cannot be subject to the deletion rule.

(5a) $\mathbf{M i}-\boldsymbol{r a} \boldsymbol{A}_{\mathrm{A}}=t u_{\mathrm{O}} \quad b a-y a=a m a ?$

$2 \mathrm{SG}-\mathrm{ERG} \quad=3 \mathrm{SG} \quad$ see-IMPFV $=$ NEG

'Don't you (sG) see it?'

(5b) Ejebucha tu-ke $e_{\mathrm{O}}=\boldsymbol{m i} \boldsymbol{i}_{\mathrm{A}} \quad b a-y a ?$ how 3SG-FM $=2 \mathrm{SG}$ see-IMPFV

'How do you (sG) see it?'

Before expanding on my proposal, which is the topic of $\mathbf{3}$ below, I provide a detailed presentation of Camp's analysis.

2. Camp's (1985) "split ergativity" analysis. According to Camp, the alternating patterns that affect Cavineña pronouns are sensitive to four factors: (1) the difference between main and subordinate clause, (2) the mood/polarity of the clause, (3) the constituent order, and (4) a $1>2>3$ person hierarchy. These four factors are discussed in turn below.

2.1. Main versus subordinate clause. Camp observes that in subordinate clauses (dependent clauses in her terminology), a pronoun in A function can only be in the "ergative" case (i.e., it must have a full form) (1985:42). In the relative clause in $(9 a)$, for example, the third-person plural pronoun in A function must occur in its full form tuna-ra (the short form tuna would be interpreted as coding the $\mathrm{O}$ function). Similarly, in the temporal adverbial clause in $(9 b)$, the first-person dual pronoun in A function must have its full form yatse-ra (the short form yatse would be interpreted as coding the $\mathrm{O}$ function). (See also tu-ra '3SG-ERG' in 10b.)

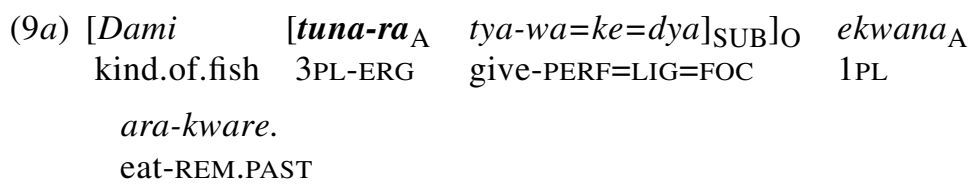

'We ate the fish which they gave us'. (Camp 1985:43) 

(9b) $\left[\text { Yatse-ra } a_{\mathrm{A}} \text { jipe-etibe-ya=ju}\right]_{\mathrm{SUB}}$ tatse-ra $a_{\mathrm{A}}$ yatse O $_{\mathrm{O}}$ 2DL-ERG approach-INCR-IMPFV=DS 3DL-ERG 1DL isara-tsa-kware. greet-COME(O)-REM.PAST

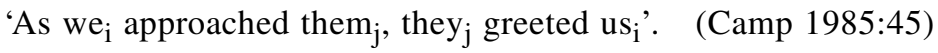

Camp also notes that in subordinate clauses, absolutive singular pronouns must occur in their full form (1985:41). As an illustration, the absolutive third-person singular pronoun can only have its full form $t u$-ke (never its short form $=t u$ ) in the temporal adverbial clauses in (10a) (in $\mathrm{S}$ function) and (10b) (in O function). (Other examples are $m i-k e$ '2SG-FM' in $18 c$ and $t u$-ke '3SG-FM' in 21d.)

(10a) Tume $\left[\boldsymbol{t u}-\boldsymbol{k} \boldsymbol{e}_{\mathrm{S}} \text { neti-tsura-ya=ju}\right]_{\mathrm{SUB}} \quad=t u_{\mathrm{A}}$ muba-kware. then 3SG-FM stand-GO.UP-IMPFV=DS $=3 \mathrm{SG}$ fear-REM.PAST

'Then when it stood up, she was afraid of it'. (Camp 1985:41)

(10b) $\left[\boldsymbol{T u}-\boldsymbol{r a} \boldsymbol{A}_{\mathrm{A}} \boldsymbol{t u}-\boldsymbol{k} \boldsymbol{e}_{\mathrm{O}} \text { iye jadya ju-atsu }\right]_{\mathrm{SUB}}$ 3SG-ERG 3SG-FM kill thus be-sS

kwa-nuka-kware. go-REITR-REM.PAST

'After he killed it, he went on'. (Camp 1985:42)

2.2. Mood/polarity. Camp claims that in main clauses of what she calls "low activity," a pronoun coding A is usually (i.e., not obligatorily) "ergative" (1985:42). "Low activity" corresponds to negation, potentiality, intention, sensation, and contrary to fact. Her examples illustrating an A pronoun coded "ergatively" in these four types of sentence are provided in (11).

(11a) Negation (first presented in 6a)

$\begin{array}{llcl}\text { Pake } & \text { metse-ra } & {[e-k w e} & u t s e k w a]_{\mathrm{O}} \\ \text { apparently } & \text { 2DL-ERG } & 1 \mathrm{SG}-\mathrm{GEN} & \text { grandchild }\end{array}$

naru-chine $=$ ama .

take.care. of-REC.PAST $=$ NEG

'Apparently you (DL) didn't take care of my grandchild'. (Camp 1985:42)

(11b) Potentiality

$\begin{array}{lllll}\text { Aishu } & =t u_{\mathrm{O}} & \boldsymbol{e}-\boldsymbol{r a} & \boldsymbol{e} \text {-iye- } \boldsymbol{u} & \text { kistiano }_{\mathrm{O}} \text { ? } \\ \text { why } & =3 \mathrm{SG} & 1 \mathrm{SG}-\mathrm{ERG} & \text { POT-kill-POT } & \text { person }\end{array}$

'Why might I kill a person?' (Camp 1985:42) 
(11c) Intention

...jutakiju barato=ju=dya $\boldsymbol{e}-\boldsymbol{r} \boldsymbol{a}_{\mathrm{A}} \quad \boldsymbol{p a}$-kemi-ti! therefore cheap=LOC=FOC 1SG-ERG HORT-buy-GO

'(If he's charging a high price at his place,) I'm going to go buy it where it's cheap!' (Camp 1985:42)

(11d) Sensation ${ }^{12}$

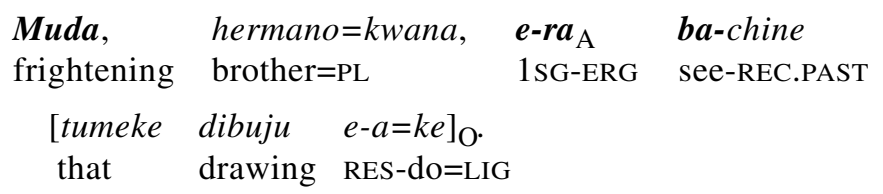

'Frightening was what I saw in the drawing, brothers!' (Camp 1985:42)

(11e) Contrary to fact ${ }^{13}$

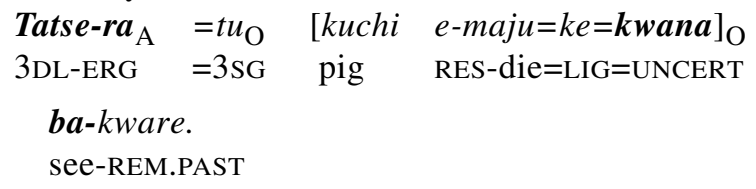

'They thought it was a dead pig'. (Camp 1985:43)

A readjustment of Camp's present claim and a reinterpretation of some of her illustrative examples are in order.

First, my data show that only intentional mood (imperative and hortative moods to be exact) has an effect on the coding of the A argument (as well as on the selection of full versus short forms of absolutive singular pronouns). In other moods (negation, potentiality, sensation, and contrary to fact), the data (including Camp's own data) show that a pronoun in A function can either have a full form, as in Camp's examples $(11 a, 11 b, 11 d, 11 e)$ or a short form, as in the examples in (12).

(12a) Negation (see short absolutive singular pronouns in $5 a$ and 29a)

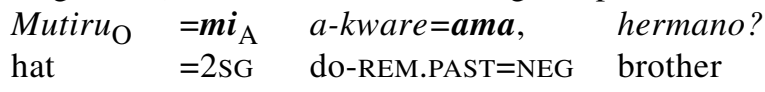

'Didn't you (SG) make (straw) hats, brother?'

\footnotetext{
${ }^{12}$ Clauses in "sensation" mood consist of the transitive perception verb $b a$ - 'see' and an adjective in secondary predicate function. The adjective refers to a property of the $\mathrm{O}$ argument referent as seen/felt/experienced by the A argument.

${ }^{13}$ Clauses in "contrary to fact" mood consist (as far as I understand Camp) of the same verb $b a$ - 'see' and the uncertainty particle $=k w a n a$ modifying the $\mathrm{O}$ (or some other constituent).
} 
(12b) Potentiality (see short absolutive singular pronouns in 11b)

Jadya $\quad t u-k e_{\mathrm{O}} \quad=\boldsymbol{m i}_{\mathrm{A}} \quad \boldsymbol{e}$ - $\boldsymbol{a}-\boldsymbol{t} \boldsymbol{i}-\boldsymbol{u}$.

thus $3 \mathrm{SG}-\mathrm{FM} \quad=2 \mathrm{SG} \quad$ POT-do-GO-POT

'Thus you (SG) might get it'. (Camp 1985:49)

(12c) Sensation

$\begin{array}{llll}\text { Muda } & \text { tu-ke } & \text { yatse }_{\mathrm{A}} & \text { ba-chine. } \\ \text { scary } & 3 \mathrm{SG}-\mathrm{FM} & 1 \mathrm{DL} & \text { see-REC.PAST }\end{array}$

'We thought (lit., saw that) it was dangerous'. (Camp 1985:41)

Note that I could not find examples illustrating short pronominal forms coding A function in clauses of so-called contrary-to-fact mood. However, as the pronoun $=t u$ ' $3 \mathrm{SG}$ ' shows in Camp's own example $(11 e)$, these clauses can at least have short forms of absolutive singular pronouns, a fact that suggests that short pronominal forms coding A are most likely to be found in these clauses as well.

Second, my data show that in imperative and hortative clauses, a pronoun in A function obligatorily has a full form, contrary to Camp's claim that this is only a tendency. This is difficult to prove when the A pronoun is a first singular (as in 11c) since short forms of first-person singular pronouns are $=\emptyset$. However, with pronouns from the rest of the paradigm, we can clearly see that a full form is obligatorily found in imperative and hortative clauses. The second-person singular pronoun in A function in the imperative clause in (13), for example, must have its full form mi-ra '2sG-ERG' (its short form $=m i$ would be ungrammatical).

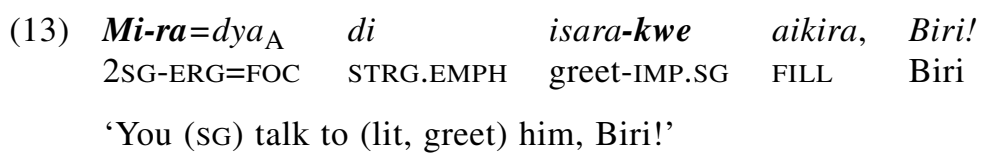

Third, my data show that in imperative and hortative clauses, absolutive singular pronouns must also have a full form, as with $m i-k e$ ' $2 \mathrm{sG}-\mathrm{FM}$ ' in the imperative clause in (14) (the short form $=m i$ would be ungrammatical in this example).

$\begin{array}{llll}\text { Bute-kwe! } & \text { Mi-ke }_{\mathrm{S}} & \text { ikwene } & \text { kueti-kwe! } \\ \text { go.down-IMP.SG } & \text { 2SG-FM } & \text { first } & \text { pass-IMP.SG }\end{array}$

'(You) go down (from the motorcycle)! You (SG) pass (on the bridge) first!'

2.3. Constituent order. Camp notes that within main clauses of "high activity" (i.e., not in imperative or hortative mood), if a pronoun coding A 
occurs sentence-initially or finally, it is obligatorily "ergative" (1985:43). In (15a), for example, the second-person singular pronoun in A function occurring in first position obligatorily has its full form mi-ra '2sG-ERG' (it cannot have its short form $=m i)$. Similarly, in $(15 b)$, the first-person plural pronoun in A function in last position in the sentence obligatorily has its full form ekwana-ra (it cannot have its short form ekwana).

(15a) Sentence-initial position (see also $m i-r a$ '2sG-ERG' in 5a)

$\begin{array}{llll}\boldsymbol{M i}-\boldsymbol{r a} & =t u_{\mathrm{O}} & \text { adeba-ya } & \text { Señor } \\ 2 \mathrm{SG}-\mathrm{ERG} & =3 \mathrm{SG} & \text { know-IMPFV } & \text { Lord }\end{array}$

'You (sG) know it, Lord'. (Camp 1985:49)

(15b) Sentence-final position

Ejene-ya datse tu-ke $e_{\mathrm{O}}$ ekwana-ra $\boldsymbol{A}_{\mathrm{A}}$.

believe-IMPFV FRUST 3SG-FM 1PL-ERG

'We believed it but we shouldn't have'. (Camp 1985:43)

Camp also observes that absolutive singular pronouns in first or last position in a sentence of "high activity" must have a full form when they code $S$ (1985:41). In (16a), for example, the second-person singular pronoun coding $\mathrm{S}$ in sentence-initial position must have its full form mi-ke (it cannot have its short form $=m i)$. Similarly, in $(16 b)$, the third-person singular pronoun coding $\mathrm{S}$ in sentence-final position must have its full form $t u$ - $k e$ (it cannot have its short form $=t u$ ).

(16a) Sentence-initial position

$$
\begin{aligned}
& \text { Mi-ke }_{\mathrm{S}} \text { bajida ena=tsewe. } \\
& 2 \mathrm{SG}-\mathrm{FM} \text { scared water=ASSOC } \\
& \text { 'You (SG) are scared of the water'. }
\end{aligned}
$$

(16b) Sentence-final position (see also mi-ke '2SG-FM' in $4 b$ )

$\begin{array}{ll}A n i-y a=d y a & \boldsymbol{t u}-\boldsymbol{k} \boldsymbol{e}_{\mathrm{S}} \\ \text { sit-IMPFV=FOC } & 3 \mathrm{SG}-\mathrm{FM}\end{array}$

'(Yes,) there are (medicinal plants) (lit., medicinal plants sit)'.

According to Camp, the sentence-initial or final position factor does not apply to absolutive singular pronouns in $\mathrm{O}$ function. However, my data show that absolutive singular pronouns in $\mathrm{O}$ function behave exactly like those in $S$ function when they occur sentence-initially or finally: they must occur in their full form, as with the third-person singular tu-ke '3SG-FM' in (17a) (in sentence-initial position) and (17b) (in sentence-final position). In neither position would the short form $=t u$ be grammatical. 
(17a) $\mathbf{T u}-k \boldsymbol{e}=$ kamadya $_{\mathrm{O}}$ shana tatse $_{\mathrm{A}}$ aikwana 3SG-FM=ONLY PITY 3DL FILL

kemi-kware.

take.out-REM.PAST

'(The grandfather and his grandson spent a whole night fishing and only caught a tiny fish.) It is the only thing that they caught, the poor guys'.

(17b) $E$-wane $=k e=r a_{\mathrm{A}}$ amena ba-ti-kware $\boldsymbol{t u}$-ke $\boldsymbol{e}_{\mathrm{O}}$. 3 - $w i f e=3=$ ERG FILL See-GO-REM.PAST 3SG-FM

'His wife went to see him'.

2.4. Person hierarchy. Camp also observes that in main clauses which are of "high activity" and where the A pronoun is not first or last, the coding of the A pronoun is sensitive to a $1>2>3$ person hierarchy (first person is higher than second/third person and second person is higher than third person). As shown by Camp, the A pronoun is coded "ergatively" (i.e., with a full form) if it is lower than the $\mathrm{O}$ pronoun on the hierarchy $(\mathrm{A}<\mathrm{O})$ (1985:44), but "absolutively" (i.e., with a short form) if it is higher than or equal to the $\mathrm{O}$ on the hierarchy $(\mathrm{A} \geq \mathrm{O})(1985: 45,50)$.

Full forms of A pronouns in $\mathrm{A}<\mathrm{O}$ situations are illustrated with the three possible combinations (A3/O1, A2/O1, and $\mathrm{A} 3 / \mathrm{O} 2)$ in (18).

(18a) $\mathrm{A} 3 / \mathrm{O} 1$ (this is $9 b$ )

$\left[\text { Yatse-ra }_{\mathrm{A}} \text { jipe-etibe-ya }=j u\right]_{\mathrm{SUB}} \quad$ tatse-ra $\boldsymbol{A}_{\mathrm{A}}$ yatse $_{\mathrm{O}}$

2DL-ERG approach-INCR-IMPFV=DS 3DL-ERG 1DL

isara-tsa-kware.

greet-COME(O)-REM.PAST

'As we ${ }_{i}$ approached them ${ }_{j}$, they greeted us $_{i}$ '. (Camp 1985:45)

(18b) A2/O1

[Riyake wekaka] mi-ra ekwana $_{\mathrm{O}}$ isara-nuka-wa. this day 2SG-ERG 1PL greet-REITR-PERF

'Today you (SG) spoke to (lit., greeted) us again'. (Camp 1985:45)

(18c) $\mathrm{A} 3 / \mathrm{O} 2$

$\left[\mathrm{Mi}^{-k e_{\mathrm{S}}} \text { chapa metse }=t i b u\right]_{\mathrm{SUB}} \quad \boldsymbol{t u}-\boldsymbol{r} \boldsymbol{a}_{\mathrm{A}} \quad=m i_{\mathrm{O}}$ 2SG-FM dog owner=REASON 3sG-ERG $=2 \mathrm{SG}$

tири-уа.

follow-IMPFV

'Since you (SG) are the dog's owner, he (dog) will follow you (SG)'. 
In these examples, the short forms of the A pronouns (i.e., tatse ' $3 \mathrm{DL}$ ', $=m i$ ' $2 \mathrm{SG}$ ', and $=t u$ ' $3 \mathrm{SG}$ ', respectively) would be ungrammatical.

Short forms of A pronouns in $\mathrm{A} \geq \mathrm{O}$ situations are illustrated with the four possible combinations (A1/O3, A1/O2, A2/O3, and A3/O3) in (19).

(19a) $\mathrm{A} 1 / \mathrm{O} 3$ (this is $12 c$ )

$\begin{array}{llll}\text { Muda } & \text { tu-ke } & \text { yatse }_{\mathrm{A}} & \text { ba-chine. } \\ \text { scary } & \text { 3SG-FM } & 2 \mathrm{DL} & \text { see-REC.PAST }\end{array}$

'We thought (lit., saw that) it was dangerous'. (Camp 1985:41)

(19b) A1/O2

$\begin{array}{llll}\text { Yusurupai } & m i-k e_{\mathrm{O}} & \boldsymbol{e k w a n a}_{\mathrm{A}} & a-y a \ldots\end{array}$

thank 2SG-FM 1PL do-IMPFV

'We thank you (because you cared for us this past week)'. (Camp 1985:45)

(19c) $\mathrm{A} 2 / \mathrm{O} 3$ (this is $5 b$ )

Ejebucha $t u-k e_{\mathrm{O}} \quad=\boldsymbol{m i}_{\mathrm{A}} \quad b a-y a$ ?

how 3 SG-FM $=2$ SG see-IMPFV

'How do you (sG) see it?'

(19d) $\mathrm{A} 3 / \mathrm{O} 3$ (this is $17 a$ )

Tu-ke=kamadya $a_{\mathrm{O}}$ shana tatse $_{\mathrm{A}}$ aikwana kemi-kware.

3SG-FM=ONLY PITY 3DL FILL take.out-REM.PAST

'(The grandfather and his grandson spent a whole night fishing and only caught a tiny fish.) It is the only thing that they caught, the poor guys'.

In these examples, the full forms of the A pronouns (i.e., yatse-ra '1DL-ERG', ekwana-ra '1PL-ERG', mi-ra '2SG-ERG', and tatse-ra '3DL-ERG', respectively) would be ungrammatical.

Camp also notes that in this same context (i.e., main clauses of "high activity" where the A pronoun is not first or last), the ordering of the A pronoun vis-à-vis the $\mathrm{O}$ pronoun, when they are contiguous, is not random but is controlled by the same $1>2>3$ person hierarchy, as follows: the lower the pronoun is on the hierarchy, the earlier it appears in the sequence (1985:44). In other words, third person precedes second/first person and second person precedes first person. This can be seen in $(18 a)-(18 c)$ and $(19 a)-(19 c)$. When the pronoun coding $\mathrm{A}$ and the pronoun coding $\mathrm{O}$ are equally ranked, it is only possible for one to occur, as is the case in $(19 d)$.

Camp notes that in this same context, the form of absolutive singular pronouns which are not first or last in the sentence is also sensitive to the hierarchy. In $\mathrm{A}<\mathrm{O}$ situations, absolutive singular pronouns have a short form 
TABLE 2

Summary of Factors Conditioning the Coding of A And the Form of Absolutive Singular Pronouns (ACCORDING TO CAMP 1985)

\begin{tabular}{lllllll}
\hline \hline & Clause & "Activity" & Position of A & Hierarchy & A & ABS SG \\
\hline$(1)$ & subordinate & any & any & any & 'ERG' & FULL \\
$(2)$ & main & "low" & any & any & 'ERG' & FULL \\
$(3)$ & main & "high" & first or last & any & 'ERG' & FULL \\
$(4)$ & main & "high" & not first or last & A $<$ O & 'ERG' & SHORT \\
$(5)$ & main & "high" & not first or last & A > O & 'ABS' & FULL \\
$(6)$ & main & "high" & not first or last & A = O & 'ABS' & SHORT \\
\hline
\end{tabular}

(as with $=m i$ ' $2 \mathrm{SG}^{\mathrm{s}}$ ' in $18 c$ ). In $\mathrm{A}>\mathrm{O}$ situations, they have a full form (as with tu-ke '3SG-FM' in $19 a$ and $19 c$ and mi-ke '2SG-FM' in $19 b$ ). In the $\mathrm{A}=\mathrm{O}$ situation, where only one pronoun can occur (either $\mathrm{A}$ or $\mathrm{O}$ ), if the pronoun is coding $\mathrm{O}$ and is singular, it has a short form (see the example with $=t u$ ' $3 \mathrm{sG}$ ' in $11 e$ ).

2.5. Summary. According to Camp, Cavineña has a single category of pronouns (table 1), with "ergative" and "absolutive" pronouns. Camp's "ergative" pronouns have a single form. Camp's "absolutive" singular pronouns have both a full form and a short form; nonsingular ones have only one (full) form. According to Camp, the way core functions are coded by pronouns follows a "split ergative" pattern conditioned by a combination of four factors: (1) difference between main and subordinate clause, (2) mood/polarity of the clause, (3) constituent order, and (4) person hierarchy. The coding of the A function by an "ergative" pronoun is said to have to do with its occurring in a subordinate clause, or being in a "low activity" mood, or occurring in sentence-initial or final position, or in combination with an $\mathrm{O}$ pronoun whose person is higher on the person hierarchy. The coding of the A function by an "absolutive" pronoun, illustrating the so-called ergative split, is said to have to do with its occurring in a main clause of "high activity" mood in a position other than sentence-initial or final and in combination with an O pronoun whose person is lower or equal on the person hierarchy. Finally, Camp shows that the alternation between full forms and short forms of absolutive singular pronouns is basically conditioned by the same factors. Camp's characterization of the Cavineña pronominal coding system is summarized in table 2.

Camp's work is interesting enough to merit closer analysis. However, her characterization of the facts of the pronominal system is not convincing (see 1.3). A proposed reanalysis to remedy these shortcomings was briefly suggested in 1.4. In the remainder of this paper, I present this reanalysis in more detail. 
3. A reanalysis. My proposal to deal with the facts raised by Camp consists of two main points: (1) recognizing a distinction between independent pronouns and bound pronouns (i.e., two distinct categories of pronouns instead of one) and (2) attributing the odd facts to the application of a morphophonological rule of suffix deletion.

I first discuss the phenomenon of second position in the language (3.1) to show that this position is a locus for various types of clitic morphemes, notably pronominal clitics. This finding is the basis for a contrast between bound pronouns, which are clitics in second position, and independent pronouns, which are free to occur elsewhere. The morphosyntactic and prosodic properties of both categories of pronouns are discussed in 3.2 (independent pronouns) and $\mathbf{3 . 3}$ (bound pronouns), followed by a reevaluation of Camp's first three conditioning factors (main versus subordinate, mood/polarity, and constituent order) (3.4). Her fourth factor (person hierarchy) is discussed in 3.5 along with the postulation of a morphophonological rule of suffix deletion that accounts for the alternation between full forms and short forms of both ergative and absolutive (singular) pronouns. The necessary recognition of an additional set of dative bound pronouns is the topic of 3.6. A fully revised table of bound pronouns is provided in 3.7.

3.1. Second position. A first step toward reevaluating the pronominal system of Cavineña is to note that the language has a large number of morphemes that are enclitics to the last phonological word of the first immediate constituent of a main clause (henceforth called second-position enclitics). These morphemes code various semantic notions having to do with evidentiality, epistemic modality, discourse status, speaker attitude, etc., as illustrated by the following.

\begin{tabular}{|c|c|c|c|}
\hline$(20)=p a$ & 'REP' & $=d i$ & 'STRG.EMPH' \\
\hline$=n i$ & 'MAYBE' & $=$ datse & 'FRUST' \\
\hline$=$ bakwe & 'CONTR' & $=$ shana & 'PITY' \\
\hline
\end{tabular}

The reportative enclitic $=p a$ is illustrated in (21). This morpheme, like the others, can only be found in a main clause (never in a subordinate clause). It is not accented and must attach phonologically to a host. The host has to be the last phonological word of the first immediate constituent of the clause. Since constituent order is free in Cavineña, second-position enclitics can attach to a whole range of constituents, such as the verb/predicate in (21a), an NP in $(21 b)$, a postpositional phrase in $(21 c)$, or an adverbial subordinate clause in $(21 d)$ (note that in this example, $=p a$ combines with and follows another second-position enclitic, $=n i$ 'MAYBE').

$$
\begin{aligned}
& \text { (21a) } E \text {-maju-u =pa }[e-k w e \quad e-b a k w a]_{S} \text {. } \\
& \text { POT-die-POT =REP 1SG-GEN 1-child }
\end{aligned}
$$




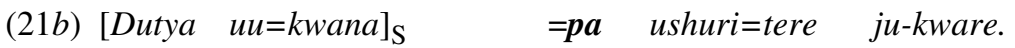
all domestic.animal $=\mathrm{PL}=\mathrm{REP}$ skinny $=\mathrm{ONLY}$ be-REM.PAST

'It is said that all the domestic animals were very skinny

(because they had not been fed for a long time)'.

(21c) $\left[\right.$ Tumeke mejiji=ju] =pa =tuna $a_{\mathrm{S}}$ tawi-nati-kware. that beach $=$ LOC $=$ REP $=3$ PL sleep-GO-REM.PAST

'It is said that they slept on that beach'.

(21d) $\left[\begin{array}{ll}T u-k e_{\mathrm{O}} & b a-t s a-t s u\end{array}\right]_{\mathrm{SUB}}=n i \quad=p a$ iba $a_{\mathrm{S}}$ diru-kware. $3 \mathrm{SG}-\mathrm{FM}$ see-COME(O)-SS =MAYBE =REP jaguar go-REM.PAST

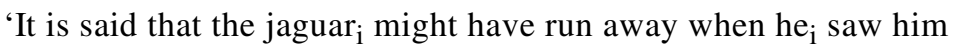
(the hunter, coming to his $\mathrm{i}_{\mathrm{i}}$ side)'.

A second step in reevaluating the pronominal system of Cavineña is to observe that the second position not only attracts the type of morphemes illustrated above (evidentials, epistemic modals, etc.) but pronouns as well. My claim is that all the pronouns discussed in (18) and (19) (repeated in 22 and 23 below), which were used to illustrate the role of the person hierarchy (2.4) (and correspond to Camp's situations 4, 5, and 6 in table 2), are secondposition clitics. ${ }^{14}$ First, observe that they are all found right after the first immediate constituent of a main clause (the boundaries of the first immediate constituent are coded by square brackets).

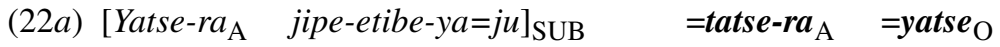
2DL-ERG approach-INCR-IMPFV $=$ DS $=3$ DL-ERG $=1 \mathrm{DL}$

isara-tsa-kware. greet-COME(O)-REM.PAST

'As we ${ }_{\mathrm{i}}$ approached them $_{\mathrm{j}}$, they ${ }_{\mathrm{j}}$ greeted us'. (Camp 1985:45)

(22b) $[$ Riyake wekaka $]=\boldsymbol{m i - r a _ { \mathrm { A } }}=\boldsymbol{e} \boldsymbol{k w a n a _ { \mathrm { O } }}$ isara-nuka-wa. this day $=2 \mathrm{SG}-\mathrm{ERG}=1 \mathrm{PL}$ greet-REITR-PERF

‘Today you (SG) spoke to (lit., greeted) us again'. (Camp 1985:45)

(22c) $\left[\text { Mi-ke } e_{\mathrm{S}} \text { chapa metse=tibu }\right]_{\mathrm{SUB}}=\boldsymbol{t u}-\boldsymbol{r a} \boldsymbol{A}_{\mathrm{A}}=\boldsymbol{m i}$ $2 \mathrm{SG}-\mathrm{FM}$ dog owner=REASON $=3 \mathrm{SG}-\mathrm{ERG}=2 \mathrm{SG}$ tupu-ya.

follow-IMPFV

'Since you (SG) are the dog's owner, he (dog) will follow you (SG)'.

\footnotetext{
${ }^{14}$ As such they are coded with an equal (=) sign. Note that I have already used the equal sign for coding the short forms of absolutive singular pronouns, which are (correctly) analyzed by Camp as clitics (see table 1).
} 
(23a) $[$ Muda $]=t u-k e_{\mathrm{O}}=y a t s e_{\mathrm{A}}$ ba-chine. scary $=3 \mathrm{SG}-\mathrm{FM} \quad=1 \mathrm{DL} \quad$ see-REC.PAST

'We thought (lit., saw that) it was dangerous'. (Camp 1985:41)

(23b) $[$ Yusurupai $]=\boldsymbol{m i}-\boldsymbol{k} \boldsymbol{e}_{\mathrm{O}}=\boldsymbol{e} \boldsymbol{w w a n a}_{\mathrm{A}} a-y a \ldots$ thank $=2 \mathrm{SG}-\mathrm{FM} \quad=1 \mathrm{PL}$ do-IMPFV

'We thank you (because you cared for us this past week)'. (Camp 1985:45)

(23c) $[$ Ejebucha $]=t \boldsymbol{t u}-\boldsymbol{k} \boldsymbol{e}_{\mathrm{O}} \quad=\boldsymbol{m i} \boldsymbol{i}_{\mathrm{A}} \quad b a-y a ?$ how $\quad=3 \mathrm{SG}-\mathrm{FM} \quad=2 \mathrm{SG} \quad$ see-IMPFV

'How do you (sG) see it?'

$\begin{array}{clll}(23 d)\left[\text { Tu }_{-} \text {ke }=\text { kamadya }\right]_{\mathrm{O}} & =\text { shana }^{15} & =\text { tatse }_{\mathrm{A}} & \text { aikwana } \\ \text { 3SG-FM=ONLY } & =\text { PITY } & =3 \mathrm{DL} & \text { FILL }\end{array}$

kemi-kware. take.out-REM.PAST

'(The grandfather and his grandson spent a whole night fishing and only caught a tiny fish.) It is the only thing that they caught, the poor guys'.

Second, note that the short forms of pronouns (corresponding to Camp's short absolutive singular pronouns and her "absolutive" pronouns coding A) are found precisely and exclusively in the sets of examples (22) and (23); see $=m i$ ' $2 \mathrm{sG}$ ' coding $\mathrm{O}$ in $(22 c)$ and all the pronouns coding $\mathrm{A}$ in (23).

Third, there are examples where a pronoun doubles up with a noun/NP coding the same argument in the same clause, as in (24) below where the $\mathrm{O}$ argument 'wild pig' is referred to by both a third-person pronoun and the noun waburasa. Interestingly, in all such cases, the pronoun is found right after the first immediate constituent of the clause.

$$
\begin{aligned}
& {[\text { Tume }]=t \boldsymbol{t u}-\boldsymbol{k}_{\mathrm{O}} \quad=e k w a n a_{\mathrm{A}} \quad \text { ba-nati-kware }} \\
& \text { then }=3 \mathrm{SG}-\mathrm{FM}=1 \mathrm{PL} \quad \text { see-GO-REM.PAST wild.pig }
\end{aligned}
$$

'Then on the way we saw a wild pig'. (Camp 1985:49)

We have seen that Cavineña also has pronouns occurring elsewhere than in second position. For example, we saw pronouns occurring sentence-initially,

\footnotetext{
${ }^{15}$ Recall that =shana 'PITY' is a second-position clitic (see list in 20). In this example, it clusters with the clitic pronoun $=$ tatse ' $3 \mathrm{DL}$ ' in second position.
} 
as with mi-ke '2SG-FM' in S function in (16a) (repeated in 25a), tu-ke '3sGFM' in O function in (17a) (repeated in 25b), and mi-ra '2SG-ERG' in A function in (15a) (repeated in 25c).

(25a) $\mathbf{M i}^{-k e_{\mathrm{S}}}$ bajida ena=tswe.

2SG-FM scared water=ASSOC

'You (SG) are scared of the water'.

(25b) $\boldsymbol{T}$ u-ke=kamadya $a_{\mathrm{O}}=$ shana = tatse $\mathrm{A}_{\mathrm{A}}$ aikwana $3 \mathrm{SG}-\mathrm{FM}=\mathrm{ONLY} \quad=\mathrm{PITY} \quad=3 \mathrm{DL} \quad$ FILL

kemi-kware. take.out-REM.PAST

'(The grandfather and his grandson spent a whole night fishing and only caught a tiny fish.) It is the only thing that they caught, the poor guys'.

$\begin{array}{llll}\text { (25c) } \begin{array}{lll}\text { Mi-ra } \\ \text { A }\end{array} & =t u_{\mathrm{O}} & \text { adeba-ya } & \text { Señor } . \\ \text { 2SG-ERG } & =3 \mathrm{sg} & \text { know-IMPFV } & \text { Lord }\end{array}$

'You (SG) know it, Lord'. (Camp 1985:49)

My claim is that pronouns that occur sentence-initially (as in 25) or anywhere other than in second position (i.e., corresponding to Camp's situations 1,2 , and 3 in table 2) belong to a different category.

If we look at pronouns occurring sentence-initially, for example, we can recall that they consistently have full forms (cf. Camp's constituent order conditioning factor [2.3]). We also find that a pronoun never doubles up with a noun/NP to code the same argument if the pronoun occurs sentenceinitially.

The claimed distinction between second-position pronouns and pronouns in other positions finds additional support if one looks at their respective prosody. Second-position pronouns, similarly to second-position morphemes listed in (20), are unaccented; they require a host to which they attach phonologically. Pronouns in other positions, on the other hand, receive independent accent and do not require any host.

The distinction also correlates with very different modification possibilities. Pronouns in second position can never be modified, while pronouns in other positions can (as can nouns/NPs). See, for example, =kamadya 'ONLY' modifying $t u-k e$ ' $3 \mathrm{sG}$ ' in sentence-initial position in (25b) and =piji 'DIM' modifying tatse-ra '3DL-ERG' in fourth position in (29b). (Other such modifiers are $=a m a$ ' $\mathrm{NEG}^{\prime},=d y a$ ' $\mathrm{FOC}$ ', etc.). 
TABLE 3

CAVInEÑa IndEPEndENT Pronouns (REVISED)

\begin{tabular}{lclll}
\hline \hline Case & Person & \multicolumn{1}{c}{ SG } & \multicolumn{1}{c}{ DL } & \multicolumn{1}{c}{ PL } \\
\hline ABS & 1 & i-ke & yatse & ekwana \\
& 2 & mi-ke & metse & mikwana \\
& 3 & tu-ke & tatse & tuna \\
ERG & 1 & e-ra & yatse-ra & ekwana-ra \\
& 2 & mi-ra & metse-ra & mikwana-ra \\
& 3 & tu-ra & tatse-ra & tuna-ra \\
GEN/DAT & 1 & e-kwe & yatse-ja & ekwana-ja \\
& 2 & mi-kwe & metse-ja & mikwana-ja \\
& 3 & tu-ja & tatse-ja & tuna-ja \\
\hline
\end{tabular}

This suggests that Cavineña does not have a single category of pronouns, as postulated by Camp, but two. There is a set of pronouns that are syntactically and prosodically independent that we can call independent pronouns. There is also a set of pronouns which are syntactically and prosodically bound and that we can call bound pronouns. The two sets are discussed in turn in the following sections.

3.2. Independent pronouns. Independent pronouns have the following properties. (1) They are accented. (2) They fill NP slots; they cannot cooccur with a noun/NP coding the same function in the same clause. (3) They are free to occur anywhere in a clause. (4) They can occur in any type of clause, whether of "low activity" or "high activity," and whether subordinate or main. (5) They can be modified. (6) They do not have alternating (i.e., full versus short) forms. They consistently code the A argument with a fully ergatively marked form and S/O arguments with full absolutive forms.

The set of independent pronouns is given in table 3 .

3.3. Bound pronouns. Bound pronouns are at first glance very similar to independent pronouns in that they have the same forms. However, they can be clearly distinguished by the following properties.

(1) Bound pronouns are enclitics. They are unaccented and require a preceding host to form an independent phonological word.

(2) Bound pronouns have a fixed position. They must attach to the last phonological word of the first immediate constituent of a (main) clause. They can combine with other second-position clitic morphemes (coding evidentiality, epistemic modality, etc.; see 20) in which case bound pronouns come last ( as shown by the sequence $=$ shana $=$ tatse ' $=\mathrm{PITY}=3 \mathrm{DL}$ ' in $23 d$; see also = $p a=$ tuna ${ }^{\prime}=$ REP $=3$ PL' in $21 c$ ). 
(3) Bound pronouns have strict ordering restrictions vis-à-vis one another according to a $1>2>3$ person hierarchy. The lower the person of the pronoun is on the hierarchy, the earlier the pronoun occurs in the sequence, regardless of the function coded. In (26a) (repeated from 18c and 22c) and (26b) (repeated from $19 c$ and 23c), the third-person bound pronoun obligatorily precedes the second-person bound pronoun, whether it codes A (in $26 a$ ) or O (in 26b).

(26a) $\left[\text { Mi-ke } e_{\mathrm{S}} \text { chapa metse=tibu }\right]_{\mathrm{SUB}}=\boldsymbol{t u}-\boldsymbol{r} \boldsymbol{a}_{\mathrm{A}}=\boldsymbol{m} \boldsymbol{i}_{\mathrm{O}}$ tupu-ya . $2 \mathrm{SG}-\mathrm{FM}$ dog owner=REASON $=3 \mathrm{SG}-\mathrm{ERG}=2 \mathrm{SG}$ follow-IMPFV 'Since you (SG) are the dog's owner, he (dog) will follow you (SG)'.

(26b) $[$ Ejebucha $]=t u-k e_{\mathrm{O}}=m i_{\mathrm{A}} \quad b a-y a ?$ how $\quad=3 \mathrm{SG}-\mathrm{FM} \quad=2 \mathrm{SG}$ see-IMPFV

'How do you (sG) see it?'

(4) Bound pronouns do not fill NP slots, a claim that is supported by the fact that they can co-occur with (in other words cross-reference/agree with) a noun/NP (or even an independent pronoun; see below) coding the same argument in the same clause, as in (27a) where the A argument 'giant anteater' is coded both by a noun bari=ra and the third-person bound pronoun $=t u-r a$, and $(27 b)$ (repeated from $1 b$ ) where the S argument 'jaguar' is coded both by a noun $i b a$ and the third-person pronoun $=t u$. (See also the "double coding" of an $\mathrm{O}$ argument in 24.)

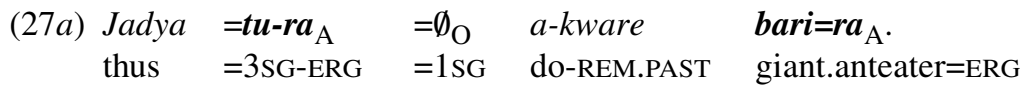

'This is what the giant anteater did to me (he poked me with its trunk)'. $\begin{array}{rllll}\text { (27b) }[\text { Tu-ke } & \text { tupuju }] & =t u_{\mathrm{S}} & \boldsymbol{i b a}_{\mathrm{S}} & \text { tsajaja-chine } . \\ \text { 3SG-FM behind } & =3 \mathrm{SG} & \text { jaguar } & \text { run-REC.PAST }\end{array}$

'The jaguar ran behind him (i.e., the jaguar chased him)'. (Camp and Liccardi 1972:33)

A bound pronoun can also co-occur with an independent pronoun coding the same argument in the same clause, a fact that is consistent with my claim that independent pronouns (but not bound pronouns) fill NP slots. This is shown in $(28 \mathrm{~V})$ below (from a recorded conversation between speakers A and V) (note that (28A) repeats 12a). As we can see, the O argument 'straw hats' is coded by both the third-person independent pronoun $t u$ - $k e$ in first position in the clause and the third-person bound pronoun $=t u-k e$ in second position. 
(28)

$\begin{array}{llll}\text { A: } \text { Mutiru }_{\mathrm{O}} & =m i_{\mathrm{A}} & \text { a-kware }=\text { ama, } & \text { hermano? } \\ \text { hat } & =2 \mathrm{SG} & \text { do-REM.PAST=NEG } & \text { brother }\end{array}$

'Didn't you (SG) make (straw) hats, brother?'

V: Aama. Tu-ke $\boldsymbol{O}_{\mathrm{O}}=\boldsymbol{t u}-\boldsymbol{k} \boldsymbol{e}_{\mathrm{O}} \quad \emptyset_{\mathrm{A}} \quad$ a-kware $=a m a$, no $3 \mathrm{SG}-\mathrm{FM}=3 \mathrm{SG}-\mathrm{FM} \quad=1 \mathrm{SG}$ do-REM.PAST $=\mathrm{NEG}$

hermano!

brother

'No! That (straw hats), I didn't make, brother!'

The co-occurrence of independent pronouns and bound pronouns coding the same argument in S and A functions in the same clause is illustrated in (29a) (S) and (29b) (A).

(29a) $\mathbf{M i}^{-k e_{\mathrm{S}}}=\boldsymbol{m i} i_{\mathrm{S}} \quad k w a-w a=a m a \quad$ escuela $=j u$.

$2 \mathrm{SG}-\mathrm{FM}=2 \mathrm{SG}$ go-PERF=NEG school=LOC

'You (SG) didn't go to school (did you?), (the priest asked me)'. (Tavo Mayo 1977:39)

(29b) Wesa-taki=ama =tatse $\boldsymbol{A}_{\mathrm{A}}$ ba-kware tatse-ra=piji $\boldsymbol{A}_{\mathrm{A}}[$ jae lift-ABIL $=$ NEG $\quad=3 \mathrm{DL}$ see-REM.PAST 3 DL-ERG $=$ DIM fish ebari=tibu]. big $=$ REASON

'They (DL) (a grandfather and his grandson) realized that they could not lift it (a fish) (lit., they saw it "unliftable") because it was a giant fish'.

(5) Bound pronouns can only occur in main clauses (not in subordinate clauses) and only in those that are not in imperative or hortative mood.

(6) Bound pronouns cannot be modified.

(7) Bound pronouns have alternating (full versus short) forms. The short forms are the result of a morphophonological rule that deletes the suffixes - $r a$ or $-k e$; see 3.5.

3.4. A first reevaluation of Camp's conditioning factors. We are now able to fully reinterpret Camp's first three conditioning factors, as follows.

MAIN VERSUS SUBORDINATE CLAUSE (factor $1 ; \mathbf{2 . 1}$ ). Bound pronouns only occur in main clauses. A pronoun in a subordinate clause is therefore an independent pronoun. Since independent pronouns only have full forms, short pronominal forms are never encountered in these types of clauses. 
MOOD/POLARITY (factor $2 ; \mathbf{2 . 2}$ ). Bound pronouns only occur in main clauses which are not imperative or hortative. Pronouns found in imperative or hortative clauses are therefore independent and, as a result, never have short forms. Recall that only Camp's "intentional” (i.e., imperative and hortative) mood is relevant among her "low activity" moods. As already discussed (2.2), my data show that there is no correlation between pronominal coding and negation, potentiality, sensation, and contrary-to-fact. According to the present proposal, sentences in these moods can either have independent pronouns (displaying full forms) or bound pronouns (displaying either full or short forms).

CONSTITUENT ORDER (factor 3; 2.3). Bound pronouns cannot occur anywhere other than in second position. A pronoun occurring in sentence-initial position is therefore an independent pronoun and, as a result, only full forms of pronouns can be found in this position. In Camp's "contrary to fact" example (11e), the A pronoun has a full form because it is an independent pronoun in first position (not because of the "contrary to fact" mood). The situation of pronouns in sentence-final position is more complex since this can involve either independent pronouns or bound pronouns (if the clause consists of only one constituent); this will be discussed below. Finally, the proposed reanalysis accounts for a fact not noted by Camp, namely, that there are examples of pronouns occurring not in second position, not in sentence-initial or final position, which still must have a full form. According to my analysis, these are independent pronouns. In Camp's "sensation" mood example $(11 d)$, the A pronoun has a full form because it is an independent pronoun in third position (not because of the "sensation" mood).

The reinterpretation of Camp's fourth conditioning factor, the person hierarchy, is tied to the postulation of a morphophonological rule of suffix deletion considered in the next section.

3.5. Deletion rule. In the preceding sections, we saw that only bound pronouns are subject to alternations between full forms and short forms. We also saw that only bound pronouns are sensitive to a person hierarchy and are ordered accordingly. In this section, I show that the short forms result from the deletion of the suffix - $r a$ 'ERG' (from ergative pronouns) or the suffix - $k e$ 'FM' (from absolutive singular pronouns) when the bound pronoun that contains the suffix occurs last or alone in second position, and only when the clause consists of more than one immediate constituent.

A closer examination of the examples containing short forms of bound pronouns reveals that these are only found when such pronouns are last (if there is more than one bound pronoun) or alone (if there is only one bound pronoun) in the second position slot. If we look at bound pronouns coding A function first, we can see this in the two examples in (30) (repeated from 
(19a and 19d). In both cases, the short bound pronouns coding A are either last (as in $30 a$ where the A bound pronoun =yatse follows the $\mathrm{O}$ bound pronoun $=t u-k e$ ) or alone (as with $=$ tatse ' $3 \mathrm{DL}$ ' in $30 b$ ).

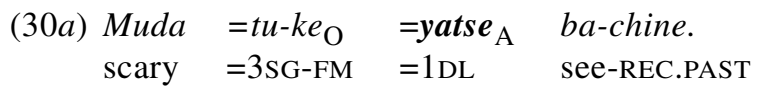

'We thought (lit., saw that) it was dangerous'. (Camp 1985:41)

(30b) $T$-ke=kamadya $a_{\mathrm{O}}=$ shana =tatse $\mathrm{A}_{\mathrm{A}}$ aikwana

$3 \mathrm{SG}-\mathrm{FM}=\mathrm{ONLY} \quad=\mathrm{PITY} \quad=3 \mathrm{DL} \quad$ FILL

kemi-kware.

take.out-REM.PAST

'(The grandfather and his grandson spent a whole night fishing and only caught a tiny fish.) It is the only thing that they caught, the poor guys'.

(See more examples in $5 b, 9 a, 10 a, 12 a-12 c, 19 b, 19 c$, and 24.)

Looking at bound pronouns coding $\mathrm{S}$ or $\mathrm{O}$ function next, we see the correlation between their having a short form and their being last or alone in second position in (31). In (31a) (repeated from 4a), the short form $=m i$ ' $2 \mathrm{SG}$ ' coding $\mathrm{S}$ is alone in second position. In (31b) (repeated from 18c), the short form $=m i$ ' $2 \mathrm{sG}$ ' coding $\mathrm{O}$ is last in second position (following the A bound pronoun $=t u-r a$ ).

(31a) Iyakwa =mi $\boldsymbol{S}_{\mathrm{S}}$ peyakeja tawi-diru-ya. now $=2 \mathrm{SG}$ other.place sleep-GO-IMPFV

'Now you're going to sleep somewhere else'. (Camp 1985:53)

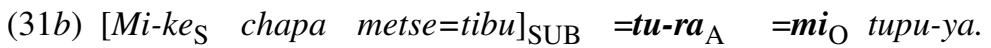
$2 \mathrm{SG}-\mathrm{FM}$ dog owner=REASON $=3 \mathrm{SG}-\mathrm{ERG}=2 \mathrm{SG}$ follow-IMPFV

'Since you (SG) are the dog's owner, he (dog) will follow you (SG)'.

(See more examples of short bound pronouns coding $\mathrm{S}$ in $1 b, 2 a$, and $29 a$, and coding $\mathrm{O}$ in $1 a, 5 a$, and $15 a$.)

Bound pronouns which are not last or alone in second position systematically have full forms, as with =tu- $r a$ '3sG-ERG' coding A in $(31 b)$ and $=t u$ - $k e$ coding $\mathrm{O}$ in $(30 a)$. (More examples showing full forms of $\mathrm{A}$ bound pronouns can be seen in $18 a$ and $18 b$, and full forms of $\mathrm{O}$ bound pronouns in $5 b, 19 b, 19 c$, and 24 . For an example of a full bound pronoun coding $\mathrm{S}$, see $37^{\prime}$, where I argue that it is followed by a dative bound pronoun.) 
If short ergative pronouns basically correspond to full ergative pronouns minus the ergative suffix $-r a$ and short absolutive singular pronouns basically correspond to full absolutive singular pronouns minus the formative suffix -ke, we can see that what happens is simply the deletion of the suffix - $r a$ 'ERG' or the suffix - $k e$ 'FM' when the pronoun is alone or last in the chain of bound pronouns. ${ }^{16}$ (Note that this is not exactly true for first-person singular pronouns where full forms alternate with $=\emptyset$; see discussion below.)

We are now able to reevaluate Camp's fourth (and last) conditioning factor, the person hierarchy (2.4). Camp noted that when the A is lower than the $\mathrm{O}$ on a $1>2>3$ hierarchy, the $\mathrm{A}$ is coded with a full form (coded "ergatively" in her terminology). However, when the A is higher than or equal to the $\mathrm{O}$ on the hierarchy, the $\mathrm{A}$ is coded with a short form (coded "absolutively"), a phenomenon that she analyzed as "split ergativity."

According to my proposal, what we are talking about here are bound pronouns, not independent pronouns. As such, they are sensitive to the person hierarchy. However, the person hierarchy only has an indirect effect on the alternation between full and short forms. The main function of the person hierarchy is to determine the order in which the bound pronouns must occur (the lower on the scale, the earlier in the sequence). When $\mathrm{A}$ is lower than $\mathrm{O}$ on the hierarchy, A comes first and $\mathrm{O}$ comes last. The ergative suffix is retained from $\mathrm{A}$. If $\mathrm{O}$ is singular, its formative suffix is deleted. ${ }^{17}$ When $\mathrm{A}$ is higher than $\mathrm{O}$ on the hierarchy, $\mathrm{O}$ comes first and $\mathrm{A}$ comes last. With $\mathrm{A}$ being last, the ergative suffix is dropped. If $\mathrm{O}$ is singular, its formative suffix is retained. When $\mathrm{A}$ is equal to $\mathrm{O}$ on the hierarchy, it is only possible for one to occur (either $\mathrm{A}$ or $\mathrm{O}$ ). In either case, with the pronoun being alone, the deletion rule must apply, deleting the ergative suffix if it is A or the formative suffix if it is a singular $\mathrm{O}$.

A constraint to the deletion rule is needed to account for the retention of the suffixes - $r a$ 'ERG' and - $k e$ 'FM' from bound pronouns in clauses consisting of only one immediate constituent, as in (32) (32a and $32 b$ are repeated from $15 b$ and $4 b$, respectively).

$\begin{array}{llll}\text { Ejene-ya } & =\text { datse } & =t u-k e_{\mathrm{O}} & =\text { ekwana-ra } \\ \text { believe-IMPFV } & =\text { FRUST } & =3 \mathrm{SG}-\mathrm{FM} & =1 \mathrm{PL}-\mathrm{ERG}\end{array}$

'We believed it but we shouldn't have'. (Camp 1985:43)

\footnotetext{
${ }^{16}$ Note that this rule is restricted to these two suffixes in the language (and, as we saw, only when they are part of the bound pronoun category). As far as I can tell, no such phenomenon is found in other parts of the grammar.

${ }^{17}$ Recall that absolutive nonsingular pronouns do not have the formative suffix -ke. They are not subject to any alternation.
} 
$\begin{array}{ll}J e-n u k a-y a=a m a & =m i-k \boldsymbol{e}_{\mathrm{S}} ? \\ \text { come-REITR-IMPFV=NEG } & =2 \mathrm{SG}-\mathrm{FM}\end{array}$

'Will you (SG) not come again?'

(32c) Jiru-ya $\quad=t u-r a_{\mathrm{A}}=m i-k e_{\mathrm{O}}$.

smell-IMPFV $=3$ SG-ERG $=2 \mathrm{SG}-\mathrm{FM}$

'He smells you (SG)'. (Camp and Liccardi 1983:149)

In all three examples, the clauses consist of only one (verbal) constituent and what appear to be bound pronouns in second position. Despite what would be expected from the posited deletion rule, the suffix - $r a$ 'ERG' does not delete in (32a), even though the A pronoun is last. Similarly, the suffix - $k e$ 'FM' does not delete in $(32 b)$ and $(32 c)$, even though the $\mathrm{S}$ pronoun is alone (in $32 b$ ) and the $\mathrm{O}$ pronoun is last (in $32 c$ ).

Recall that Camp accounted for examples like (32a) (with retention of the ergative suffix) by saying that it was due to a constituent order conditioning factor: a pronoun coding A in sentence-final position must have a full form (must be coded "ergatively") (2.3). According to my proposal, the retention of the ergative and formative suffixes in these clauses could be explained if we analyzed the pronouns as independent (as opposed to bound). However, this does not appear to be the case, notably because when they are in a sequence, the pronouns in these examples are strictly ordered according to the person hierarchy (recall that independent pronouns do not have ordering restrictions); $\mathrm{O} 3$ precedes $\mathrm{A} 1$ in ( $32 a$ ) and $\mathrm{A} 3$ precedes $\mathrm{O} 2$ in (32c).

The stance that I take here is that we are dealing with bound pronouns but the deletion rule carries a constraint that it cannot apply in clauses which consist of only one immediate constituent, in other words when the second position is also the last position in a main clause. ${ }^{18}$

The characterization of the morphophonological effects of the deletion rule must also be adapted to first-person singular bound pronouns (i.e., ergative $=\mathrm{e}-\mathrm{r} a$ and absolutive $=i-k e$ ). When these bound pronouns are in a position where the rule can apply, they are deleted altogether (i.e., there is no short form $=e$ or $=i$ left). In other words, the rule not only deletes the ergative or the formative suffix but the bound pronoun root/stem as well. This can be seen in the following examples, with full deletion of the A bound pronoun $e-r a$ in (33a), of the $\mathrm{S}$ bound pronoun $i-k e$ ' $1 \mathrm{SG}-\mathrm{FM}$ ' in (33b) (repeated from $2 b$ ), and of the $\mathrm{O}$ bound pronoun $i-k e$ ' $1 \mathrm{sG}-\mathrm{FM}$ ' in $(33 c)$.

\footnotetext{
${ }^{18}$ Note that the motivation for such a constraint is an interesting question which needs further study.
} 
(33a) Ebipukaka=tsewe $=t u-k e_{\mathrm{O}} \quad \emptyset_{\mathrm{A}} \quad$ iye-kware. fist=ASSOC $\quad=3 \mathrm{SG}-\mathrm{FM} \quad=1 \mathrm{SG} \quad$ kill-REM.PAST

'I killed it (a monkey) with my fist'.

(33b)

$$
\begin{aligned}
& J u-t i-k w a r e=d y a \quad=\emptyset_{\mathrm{S}} \quad[\text { Arauna }=k w a n a=j a \\
& \text { be-GO-REM.PAST }=\mathrm{FOC} \quad=1 \mathrm{SG} \quad \text { Araona. } \text { person }=\mathrm{PL}=\mathrm{GEN} \\
& \text { epu=ju]. } \\
& \text { village }=\text { LOC }
\end{aligned}
$$

'I arrived at the village of the Araonas'.

(33c) Jida=dya $=$ tuna-ra $a_{\mathrm{A}}=\emptyset_{\mathrm{O}}$ ba-tsa-kware. good=FOC $=3$ PL-ERG $=1 \mathrm{SG} \quad$ see-COME(O)-REM.PAST

'They received me (lit., saw me as I came) very well'.

Note that even though the "short forms" of first-person singular bound pronouns are $\emptyset$, they still function similarly to short forms of other bound pronouns (which have an overt realization). As can be seen in (33a) and (33c), $\emptyset$-forms of first-person singular bound pronouns act as the "last bound pronoun" in second position. If this were not the case, the suffix -ke should drop from the bound pronoun $=t u-k e$ in $(33 a)$ and the suffix $-r a$ from the bound pronoun =tuna-ra in (33c). Furthermore, consistent with what happens with other bound pronouns, the deletion rule cannot apply to first-person singular bound pronouns when the clause consists of only one immediate constituent and therefore their full forms must occur, as in (34a)-(34c) (compare $33 a-33 c$ ).

$$
\begin{aligned}
& \text { (34a) Iye-ya =tu-ke } e_{\mathrm{O}}=\boldsymbol{e}-\boldsymbol{r} \boldsymbol{a}_{\mathrm{A}} \text {. } \\
& \text { kill-IMPFV }=3 \mathrm{sG}-\mathrm{FM} \quad=1 \mathrm{sG}-\mathrm{ERG}
\end{aligned}
$$

'I'm going to kill it (a jaguar)'.

(34b) Kwa-kware $=\boldsymbol{i}-\boldsymbol{k} \boldsymbol{e}_{\mathrm{S}}$.

go-REM.PAST $=1 \mathrm{SG}-\mathrm{FM}$

'I went'.

(34c) Enapa-wa =taa =tuna-ra $a_{\mathrm{A}}=\boldsymbol{i}-\boldsymbol{k} \boldsymbol{e}_{\mathrm{O}}$.

cry.for-PERF $=$ EMPH $=3$ PL-ERG $\quad=1 \mathrm{SG}-\mathrm{FM}$

'They (my dogs) cried for me'.

In a number of examples provided earlier, the forms of the pronouns used still do not appear to be accounted for by my proposed morphophonological rule of suffix deletion. Such is the case for the sequence $=$ tu e-ra '=3SG 1sG-ERG' in Camp's example $(11 b)$, repeated below. 


$$
\begin{aligned}
& \text { (11b) } \begin{array}{lllll}
\text { Aishu } & =t u_{\mathrm{O}} & \boldsymbol{e}-\boldsymbol{r} \boldsymbol{a}_{\mathrm{A}} & \text { e-iye- } u & \text { kistiano }_{\mathrm{O}} ? \\
\text { why } & =3 \mathrm{SG} \quad 1 \mathrm{SG}-\mathrm{ERG} & \text { POT-kill-POT } & \text { person }
\end{array} \\
& \text { 'Why might I kill a person?' } \quad(\text { Camp 1985:42) }
\end{aligned}
$$

In this example, both $\mathrm{O}$ and $\mathrm{A}$ pronouns appear to be bound pronouns in second position: they both occur next to each other, right after the first immediate constituent of a main clause which is not in imperative or hortative mood, and they are ordered vis-à-vis one another according to the person hierarchy (O3 precedes A1). However, the deletion rule does not apply as expected. If the pronouns $\mathrm{A}$ and $\mathrm{O}$ were bound pronouns as suggested above, the rule should apply to the A pronoun, yielding $=\emptyset$, but not to the $\mathrm{O}$ pronoun, leaving $=t u-k e$. However, exactly the opposite occurs. The rule applies to the $\mathrm{O}$ pronoun but not to the A pronoun.

This suggests a different interpretation where only $\mathrm{O}$ is a bound pronoun; $\mathrm{A}$ is an independent pronoun in third position. As such, $\mathrm{O}$ is alone in second position and the deletion rule only applies to it, deleting its formative suffix $-k e$. Since $\mathrm{A}$ is an independent pronoun, it can only have a full form.

3.6. Dative bound pronouns. The full array of alternating patterns found with pronominal forms in Cavineña cannot be accounted for unless we reassess Camp's so-called genitive pronouns (see table 1) and conclude (1) that the forms in question can have dative functions and (2) that Cavineña has both dative independent pronouns and dative bound pronouns.

The dative function of the "genitive" series was illustrated in 1.2; there I showed that Camp's "genitive" series of pronouns could either operate at the NP level (in genitive function), as with tuna-ja '1PL-GEN' in (35a) (repeated from 7), or at the clause level (in dative function), as with $e$ - $k w e$ '1SG-DAT' in $(35 b)$ (repeated from 8$)$.

$$
\begin{array}{rllll}
\text { (35a) } \text { Tibu } r a_{\mathrm{A}} & =\emptyset_{\mathrm{O}} & \text { duju-kware } & {[\text { tuna-ja }} & \text { epu=ju }] . \\
\text { Tibu }=\mathrm{ERG} & =1 \mathrm{SG} & \text { take-REM.PAST } & \text { 3PL-GEN } & \text { village=LOC }
\end{array}
$$

'Tibu took me to their village'.

(35b) E-kwe ani-kware $\quad[\text { maletero arida }=k e]_{S}$.

1SG-DAT sit-REM.PAST bag big=LIG

'I had a big bag (lit., a big bag sat to me)'.

In this section, I show that Cavineña has two distinct categories of clauselevel dative pronouns: a category of independent dative pronouns (like $e$ - $k w e$ in $35 \mathrm{~b}$ ) and a category of bound (second-position) dative pronouns.

Evidence for a category of dative bound pronouns enclitics in second position comes from the need to reinterpret a number of Camp's examples, notably (11a) (repeated here). 


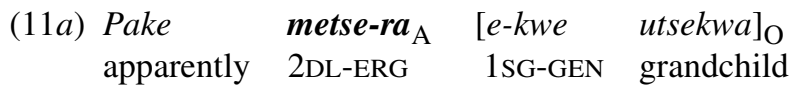

naru-chine $=$ ama .

take.care. of-REC.PAST $=\mathrm{NEG}$

'Apparently you (DL) didn't take care of my grandchild'. (Camp 1985:42)

This example is problematic because it seems to have an A bound pronoun alone in second position whose ergative suffix - $r a$ does not drop even though the clause consists of more than one immediate constituent.

The reason the ergative suffix is retained in metse-ra in this example, however, is that this pronoun is not alone in second position. ${ }^{19}$ It combines with the pronoun ekwe, which should be analyzed as a (second-position) dative bound (enclitic) pronoun, as opposed to Camp's analysis of it as a genitive independent pronoun. According to the person hierarchy, the first-person ekwe follows the second-person metse-ra since it is higher, and as a result the ergative suffix - $r a$ does not drop.

To understand why ekwe cannot be a genitive pronoun in this example, we need to know that the term for 'grandchild' is inalienably possessed in Cavineña. Inalienably possessed nouns in Cavineña take obligatory person inflections (or special forms of the noun) to indicate their possessor, as with $e$ - '1 $\mathrm{SG}$ ' prefixed to wane 'wife' in (36).

$$
\begin{array}{lll}
\boldsymbol{E}-\boldsymbol{w a n e}=r a_{\mathrm{A}} & =\emptyset_{\mathrm{O}} & \text { peta }-y a . \\
1-\text { wife }=\mathrm{ERG} & =1 \mathrm{sG} & \text { look.at-IMPFV }
\end{array}
$$

'My wife was looking at me'.

In addition to the person inflections, the possessor of an inalienably possessed noun can optionally be expressed by a genitive pronoun (or a genitive NP) (see, for example, ekwe e-bakwa 'my son' in $21 a$, where a first-person genitive pronoun is used in addition to the obligatory first-person inflection $e$-).

The form utsekwa in (11a) actually means 'your grandchild' (the form meaning 'my grandchild' is the special form eketsekwa). This reading is also confirmed by the context of the story from which this example is originally taken (Tavo Mayo 1977:12), where (11a) is said by a father to his parents about his son.

In other words, if ekwe is a genitive pronoun coding the possessor of 'grandchild' in this example, its first-person possessor reading does not match with the second-person possessor reading of the form used for 'grandchild'.

\footnotetext{
${ }^{19}$ Note that Camp accounted for the full form of the ergative pronoun in this example by her mood/polarity conditioning factor. However, as I have shown, there is no correlation between negative mood and the forms of the pronouns.
} 
This indicates that ekwe does not code the possessor of 'grandchild' in this example and that it is not a genitive pronoun.

The position taken here is that ekwe is a dative bound pronoun in second position and that (11a) should be coded, glossed, and translated as: ${ }^{20}$

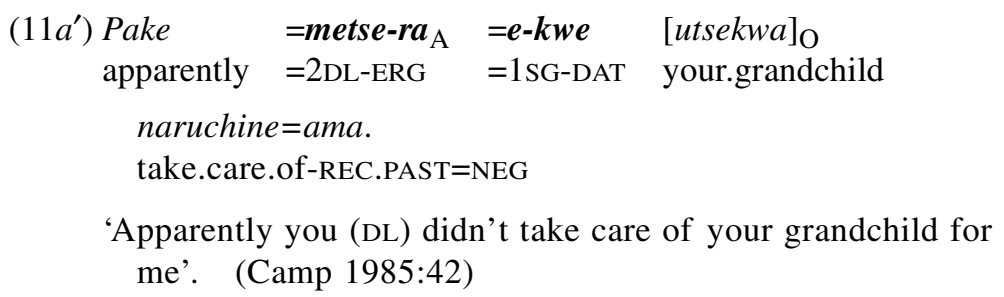

A distinction must therefore be made between independent pronouns and bound pronouns (these again having the same forms). The same kind of evidence that justified the distinction between absolutive/ergative independent pronouns and absolutive/ergative bound pronouns is also available for the distinction between dative independent pronouns and dative bound pronouns:

(1) Dative bound pronouns are unaccented enclitics. Dative independent pronouns are accented exactly like any independent phonological word.

(2) Dative bound pronouns must occur in second position. Dative independent pronouns fill dative NP slots and can occur anywhere a dative NP can.

(3) Dative bound pronouns are ordered vis-à-vis absolutive and ergative bound pronouns according to the same person hierarchy. ${ }^{21}$ Dative independent pronouns have no ordering restrictions vis-à-vis other pronouns.

(4) Dative bound pronouns can only occur in main clauses (not in subordinate clauses) which are not imperative or hortative. Dative independent pronouns can occur in any type of clause.

(5) Dative bound pronouns cannot be modified. Dative independent pronouns can be modified as any noun/NP in dative function.

(Note that the deletion rule never applies to the dative suffix, whether - $k w e$ for first- and second-person singular or $-j a$ for the rest of the paradigm.)

The recognition of a category of dative bound pronouns also allows us to make sense of a very striking (although ill-formulated) observation made by Camp, who says that there is a correlation between absolutive singular pronouns being coded by full forms and their contiguity to "genitive" pronouns $(1985: 41)$, as in:

\footnotetext{
${ }^{20}$ The exact meaning of dative bound pronouns requires further work. As far as I can tell, they can code a possessor, a recipient, an experiencer, or an "affected" participant (reminiscent of what is sometimes referred to as the "ethical dative" in the literature).

${ }^{21}$ Note that the situation is slightly more complicated. Dative bound pronouns can combine with absolutive and/or ergative bound pronouns referring to the same person. However, they are not allowed to occur with any combinations of A and O. See full discussion in Guillaume (2004:606).
} 
TABLE 4

CAVineña Bound Pronouns (REvised)

\begin{tabular}{lclll}
\hline \hline Case & Person & \multicolumn{1}{c}{ SG } & \multicolumn{1}{c}{ DL } & \multicolumn{1}{c}{ PL } \\
\hline ABS & 1 & $=\emptyset($ ike $)$ & $=$ yatse & $=$ ekwana \\
& 2 & $=m i(-k e)$ & $=$ metse & $=$ mikwana \\
& 3 & $=t u(-k e)$ & $=$ tatse & $=$ tuna \\
ERG & 1 & $=\emptyset(e-r a)$ & $=$ yatse $(-r a)$ & $=$ ekwana $(-r a)$ \\
& 2 & $=m i(-r a)$ & $=$ metse $(-r a)$ & $=$ mikwana $(-r a)$ \\
& 3 & $=t u(-r a)$ & $=$ tatse $(-r a)$ & $=$ tuna $(-$ ra $)$ \\
DAT & 1 & $=e-k w e$ & $=$ yatse $-j a$ & $=$ ekwana $-j a$ \\
& 2 & $=m i-k w e$ & $=$ metse $-j a$ & $=$ mikwana $-j a$ \\
& 3 & $=t u-j a$ & $=$ tatse $-j a$ & $=$ tuna $-j a$ \\
\hline
\end{tabular}

(37) Tuwa tu-ke $\boldsymbol{e}_{\mathrm{S}}$ [e-kwe ujeje $]_{\mathrm{S}}$ ani-ya. there 3SG-FM 1SG-GEN pain sit-IMPFV

'I have a pain (lit., my pain sits) there (in my stomach)'.

If we reformulate this observation according to my reanalysis, the firstperson pronoun $e$ - $k w e$ in this example is not a genitive pronoun (within the S NP) but a dative bound (enclitic) pronoun in second position. Since the first-person dative bound pronoun is higher on the hierarchy than its cooccurring third-person bound pronoun (coding $\mathrm{S}$ ), it must follow it according to the principles of the hierarchy. As a result, the deletion rule cannot apply to the third-person absolutive bound pronoun. A more adequate coding, glossing, and translation of (37) is:

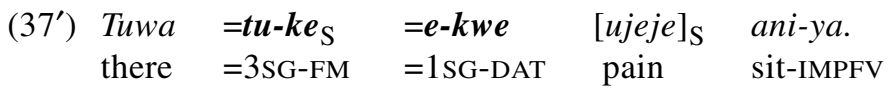

'I have a pain there (in my stomach) (lit., a pain sits there to me)'.

3.7. Bound pronouns table. I am now able to present a fully revised table of bound pronouns (table 4 ). The parentheses in table 4 indicate morphological material that is dropped when the bound pronoun undergoes the deletion rule.

4. Conclusions. South American languages are claimed to have "more diverse kinds of ergative systems and ergative splits than those from any other part of the word" (Dixon 1994:xv). At the same time, the South American continent, and more specifically the Amazon basin, is also said to be "the least known and least understood linguistic region in the world" (Dixon and Aikhenvald 1999:1). This makes the study of these languages and their ergative properties of tremendous interest for today's linguists.

Cavineña is an interesting example of such Amazonian languages with very peculiar ergative systems that need to be explained and understood. Camp's (1985) early study attracted attention to the problem, but her "split 
ergativity" analysis failed to articulate it appropriately. In this study I have shown that the oddities of the Cavineña pronominal system can be explained if we recognize a simple distinction between two categories of pronouns, independent and bound, and a morphophonological rule of case-suffix deletion. My findings can be summarized as follows.

(1) Cavineña is not a split ergative language, at least with respect to its pronominal system. I have shown that the short forms of pronouns that code A arguments in some cases are in fact underlyingly ergative. I have also shown that $\mathrm{O}$ arguments never take a distinct accusative case marking. In other words, core arguments in Cavineña are consistently coded according to an ergative/absolutive pattern (i.e., $A \neq S=O$ ), never according to a nominative/accusative pattern (i.e., $\mathrm{A}=\mathrm{S} \neq \mathrm{O}$ ).

(2) Cavineña has two distinct categories of pronouns: independent pronouns and bound pronouns. Even though they have the same forms, they have very different morphosyntactic and prosodic properties. Independent pronouns fill NP slots and can occur in any context an NP can. Bound pronouns are enclitics in second position in certain types of main clauses. They are the equivalent of verb/predicate person markers in other languages.

(3) There are three sets of bound pronouns: ergative, absolutive, and dative. They are ordered according to a person hierarchy. The lower the person of the pronoun is on the hierarchy, the earlier it appears in the clitic chain.

(4) The ergative suffix - $r a$ 'ERG' of ergative bound pronouns and the formative suffix - $k e$ ' $F M$ ' of absolutive singular pronouns are deleted ${ }^{22}$ if the pronoun is last or alone in second position and if the main clause consists of more than one immediate constituent. In other words, the short forms coding A arguments (and the short forms coding S/O arguments) are primarily the result of the application of a simple morphophonological process of deletion and are only indirectly conditioned by factors such as differences between main versus subordinate clause, mood, constituent order, and person hierarchy.

The Cavineña pronominal system as analyzed here certainly makes the language look less "exotic," at least as far as its system of coding grammatical functions is concerned. ${ }^{23}$ However, what has been gained is typological plausibility, theoretical adequacy, explanatory power, and data suitability. I hope that the present study will also contribute to the idea that Amazonian/South American languages are not as "abnormal" as they are often made out to be. ${ }^{24}$

${ }^{22}$ In the case of first-person singular, it is the full form of the pronoun that is deleted.

${ }^{23}$ The so-called split ergative system of Cavineña has been the hallmark of the language in the linguistic literature (see references made to it in Dixon 1994:106-7, Aikhenvald and Dixon 1999:366-67, and Adelaar and Muysken 2004:421-22, for example).

${ }^{24}$ This is in line with the "de-exoticization" approach proposed by Grinevald and Seifart (2004) in their study of nominal classification systems in the Amazonian region. 


\section{REFERENCES}

Adelaar, Willem F. H., and Pieter C. Muysken. 2004. The Languages of the Andes. Cambridge: Cambridge University Press.

Aikhenvald, Alexandra Y., And R. M. W. Dixon. 1999. Other small families and isolates. The Amazonian Languages, ed. R. M. W. Dixon and Alexandra Y. Aikhenvald, pp. 34184. Cambridge: Cambridge University Press.

Bickel, Balthasar, and Johanna Nichols. Forthcoming. Inflectional morphology. Language Typology and Syntactic Description, 2nd ed., ed. Timothy Shopen. Cambridge: Cambridge University Press.

CAMP, Elizabeth L. 1985. Split ergativity in Cavineña. IJAL 51:38-58.

Camp, Elizabeth L., And Millicent R. Liccardi. 1972. Quiero Contarles Unos Casos del Beni; Castellano y Cavineña. Cochabamba: Instituto Lingüístico de Verano.

1978. Cavineña pronouns in relation to theme and topic. Work Papers of the Summer Institute of Linguistics, ed. Ursula Wiesemann, pp. 21-51. Riberalta: Summer Institute of Linguistics.

1983. Pronombres en Cavineña con relación al tema. Revista Latinoamericana de Estudios Etnolingüísticos 3:121-59.

. 1989. Diccionario Cavineña-Castellano Castellano-Cavineña con Bosquejo de la Gramática Cavineña. Dallas: Summer Institute of Linguistics.

Comrie, Bernard. 1978. Ergativity. Syntactic Typology: Studies in the Phenomenology of Language, ed. W. P. Lehmann, pp. 329-74. Austin: University of Texas Press.

Dixon, R. M. W. 1972. The Dyirbal Language of North Queensland. Cambridge: Cambridge University Press.

. 1979. Ergativity. Language 55:59-138.

1994. Ergativity. Cambridge: Cambridge University Press.

.2002. Australian Languages: Their Nature and Development. Cambridge: Cambridge University Press.

Dixon, R. M. W., and Alexandra Y. Aikhenvald. 1999. Introduction. The Amazonian Languages, ed. R. M. W. Dixon and Alexandra Y. Aikhenvald, pp. 1-21. Cambridge: Cambridge University Press.

DonaldSon, TAMSIN. 1980. Ngiyambaa: The Language of the Wangaaybuwa. Cambridge: Cambridge University Press.

Grinevald, Colette, and Frank Seifart. 2004. Noun classes in African and Amazonian languages: Towards a comparison. Linguistic Typology 8:243-85.

Guillaume, Antoine. 2004. A grammar of Cavineña, an Amazonian language of northern Bolivia. Ph.D. dissertation, La Trobe University.

Hale, Kenneth L. 1973. Person marking in Walbiri. A Festschrift for Morris Halle, ed. S. R. Anderson and Paul Kiparsky, pp. 308-44. New York: Holt, Rinehart \& Winston.

LaZARD, Gilbert. 1994. L'actance. Paris: Presses Universitaires de France.

Payne, Thomas. 1997. Describing Morphosyntax: A Guide for Field Linguists. Cambridge: Cambridge University Press.

Silverstein, Michael. 1976. Hierarchy of features and ergativity. Grammatical Categories of Australian Languages, ed. R. M. W. Dixon, pp. 112-71. Canberra: Australian Institute of Aboriginal Studies.

Steele, Susan. 1976. On the count of one. Linguistic Studies Offered to Joseph Greenberg on the Occasion of His Sixtieth Birthday, ed. Juillant Alphonse, pp. 591-613. Saratoga, Calif.: Anma Libri.

Tavo Mayo, Victor. 1977. Yahua Buricuare Que: La Tierra Se Partió. Riberalta: Instituto Lingüístico de Verano. 